\title{
Latest Development on Pulsed Laser Deposited Thin Films for Advanced Luminescence Applications
}

\author{
Simon N. Ogugua ${ }^{1}\left(\mathbb{D}\right.$, Odireleng Martin Ntwaeaborwa ${ }^{2}$ and Hendrik C. Swart ${ }^{1, *(D)}$ \\ 1 Department of Physics, University of the Free State, Bloemfontein ZA-9300, South Africa; \\ Oguason@yahoo.com \\ 2 Department of Physics, University of Johannesburg, P.O. Box 524, Aukland Park ZA-2006, South Africa; \\ ntwaeab@gmail.com \\ * Correspondence: swarthc@ufs.ac.za
}

Received: 15 October 2020; Accepted: 29 October 2020; Published: 9 November 2020

\begin{abstract}
Currently, pulsed laser deposition (PLD) is a widely used technique to grow thin films for academic research and for industrial applications. The PLD has superior advantages including versatility, control over the growth rate, stoichiometric transfer and unlimited degree of freedom in the ablation geometry compared to other deposition techniques. The primary objective of this review is to revisit the basic operation mechanisms of the PLD and discuss recent modifications of the technique aimed at enhancing the quality of thin films. We also discussed recent progress made in the deposition parameters varied during preparation of luminescent inorganic oxide thin films grown using the PLD technique, which include, among others, the substrate temperature. The advanced technological applications and different methods for film characterization are also discussed. In particular, we pay attention to luminescence properties, thickness of the films and how different deposition parameters affect these properties. The advantages and shortcomings of the technique are outlined.
\end{abstract}

Keywords: PLD; luminescence; thin films

\section{Introduction}

Of late, different physical vapor deposition (PVD) techniques used for coating or thin film growth on solid substrates, such as molecular beam epitaxy (MBE), electron beam physical vapor deposition (EBPVD), pulsed laser deposition (PLD), arc discharge, reactive sputtering and ion beam sputtering, have been used extensively in laboratory research and industrial applications. Among these techniques, PLD have some distinguished capabilities such as the ability to transfer stoichiometry of the material from target to the substrate, high deposition rate, flexibility in wavelength and power density and the ability to deposit multiple layers. The PLD is based on the capability of laser radiation, usually in the ultraviolet (UV) region, to interact efficiently with a solid-state or liquid target resulting in ablation of materials from the target surface and subsequent deposition on a substrate. Depending on the properties of the laser and the target material, the interaction between the laser and the target material is capable of creating a diverse microscopic process, which leads to the local heating and subsequently vaporization of the material. Although the PLD technique was first reported in 1965 [1], the major breakthrough was reported in 1987 when Dijkkamp et al. [2] used the technique to grow $\mathrm{YBa}_{2} \mathrm{Cu}_{3} \mathrm{O}_{7}$ thin films. Over the past 15 years, the PLD has evolved from an academic curiosity into a broadly applicable technique for thin film deposition. Today, different thin film materials including phosphors, complex oxides, polymer-metal composites, nitrides, borides, carbides and even biological materials have been deposited successfully using the PLD technique [3-6]. Our main interest in PLD is the fact that it can be used for the fabrication of efficient phosphor thin films [7,8]. In addition, the PLD has been lately used to fabricate devices such as photovoltaic cells, electrostimulators, photodetectors, 
light emitting diodes (LEDs) and superconductors. Considering its utility, only a few synthesis techniques have gained such a rapid popularity in both academic research and industrial applications. Hence, it is worth reviewing the fundamentals of and recent progress made in academic research using this unique research technique.

Herewith a brief background on the principle of operation and some advantages and disadvantages related to the PLD technique are presented. A comprehensive review of luminescence properties, thickness of the films deposited using the PLD and how different deposition parameters such as time, atmosphere (environment), substrate temperature, background gas pressure, the distance between substrate and the target is presented. We also discuss recent modifications of the PLD, and how these modifications improved the quality of the deposited films. In addition, we also discuss some recent applications of the PLD.

\section{Background and Theory}

Conceptually, PLD is a very simple technique, which involves the collection of material removed from a target under a pulsed laser irradiation on a nearby substrate. Among other thin film deposition techniques, the PLD has many advantages, which include the controllable rate of film deposition by adjusting the laser parameters, deposition time, target to substrate distance, deposition time and changing the background gas. The key features of the PLD include congruent transfer of the target material to the substrate (i.e., transfer of the stoichiometry of the target material on the substrate). The ability to deposit multi and novel layers by irradiation of consecutive target of individual materials. Deposition at extremely high temperature and high rate.

Contrary to the simplicity of the system set-up, the principle of PLD involves four complex physical phenomena, which include laser beam-target interaction, ablation dynamics and plume formation, ablated materials evaporation onto the substrate and nucleation and growth of thin films.

\subsection{Laser Beam-Target Interaction}

To minimize the amount of energy lost due to carrier or thermal diffusion during absorption, short laser pulses with a wavelength strongly absorbed by the material are recommended. To avoid overlapping between the laser beam and the plume, the beam was irradiated onto the target at an incident angle of $45^{\circ}$ as shown in Figure 1. The ability of lasers to operate in the Q-switch mode (laser ability to produce a pulsed output beam) enabled the femtosecond, excimer (XeCl $308 \mathrm{~nm}, \mathrm{KrF} 248 \mathrm{~nm}$ and ArF $193 \mathrm{~nm})$, ruby (694 nm) and Nd:YAG (1064 mm, $532 \mathrm{~nm}, 355 \mathrm{~nm}$ and $266 \mathrm{~nm})$ to deposit an efficient amount of energy into a thin layer of the target.

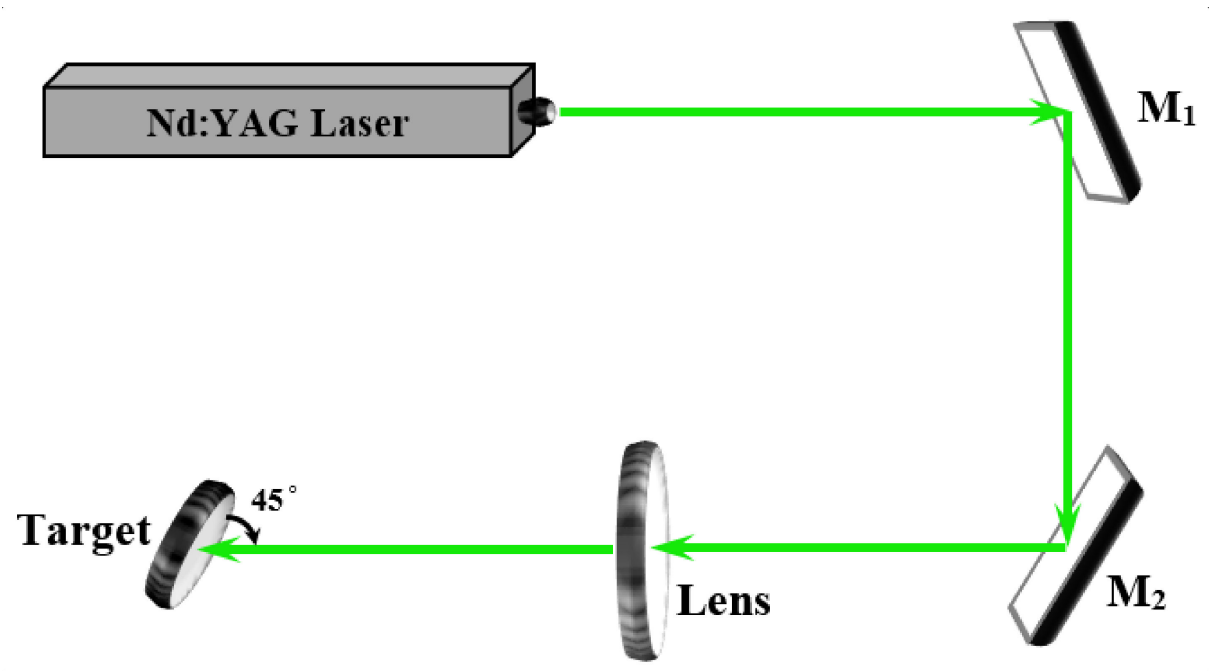

Figure 1. Schematic diagram illustrating the interaction of the laser beam with the target, $M=$ mirror. 
When an incident laser beam hits the surface of the target, it is absorbed and energy is transferred to the electrons in a material. The absorbed energy causes oscillations of the electrons in the material. The energy per unit area absorbed by the target material is a function of the fluence (time integral of laser intensity over the pulse duration) of the laser. The average beam fluence during the film deposition is similar to those needed to heat the target material above its melting temperature and trigger evaporation. The underlying principle behind evaporation of the target material upon laser beam absorption includes collision cascade among the atoms in the material, oscillation of the electrons, electron excitation and electron-lattice (ions) energy transfer. Once the energy transferred by the laser beam to a single atom exceeds its binding energy, the atom is ejected from the surface of the material [9]. The ejection of the atom is followed by a snapping sound and bright-colored plasma (plume) of the emitted particles. The intensity of the laser beam hitting the surface of the target is defined by Lambert-Beer's law [10] given by Equation (1):

$$
I(x)=I\left(x_{0}\right) e^{-\alpha\left(x-x_{0}\right)}
$$

where $I(x)$ is the reduced intensity at an ablated layer of thickness $x$ below the surface of the target, $I\left(x_{0}\right)$ is the intensity before the laser beam hits the target and $\alpha$ is the absorption coefficient of the target material. The optical penetration depth $(\delta)$ (attenuation length) is given by Equation (2) [11]:

$$
\delta=\frac{1}{\alpha}
$$

The absorption coefficient of a material is related to the refractive index ( $n$ ) by Equation (3) [12]:

$$
\alpha=\frac{4 \pi \kappa_{\alpha}}{\lambda}=\frac{4 \pi n \kappa_{0}}{\lambda}
$$

where $\lambda=2 \pi c \omega$ is the laser wavelength [9], $c$ is the speed of light, $\omega$ is the angular frequency, $\kappa_{\alpha}=n \kappa_{0}$ is the absorption index and $\kappa_{0}$ is the attenuation index. Equations (2) and (3) show that $\delta$ is directly proportional to $\lambda$ (i.e., inversely proportional to energy of the laser light) and inversely proportional to the refractive index $(\mathrm{n})$ of the material.

\subsection{The Dynamics of Ablation of Materials and Plume Formation}

Laser ablation has been analyzed using different models, namely mechanical, photochemical, thermal, photophysical and the defect model. In these models, ablation was treated as the dominant mechanism. The ablation process starts with a single or multi-phonon excitation in the target material. The optical properties of the material are changed with an increasing temperature by the instantaneous conversion of the excitation energy into heat. Thermal ablation occurs when the temperature at the surface of the target material is increased, without the surface melting [13]. The ablation threshold ranges between 0.1 and $1 \mathrm{~J} / \mathrm{cm}^{2}$ depending on the target material and the laser wavelength [9]. The ionization of the target material induces plasma (plume) formation immediately when the ablation threshold of the material is reached. The plume with stoichiometry similar to that of the target material is collected on a substrate placed at a relatively short distance from the target (Figure 2). 


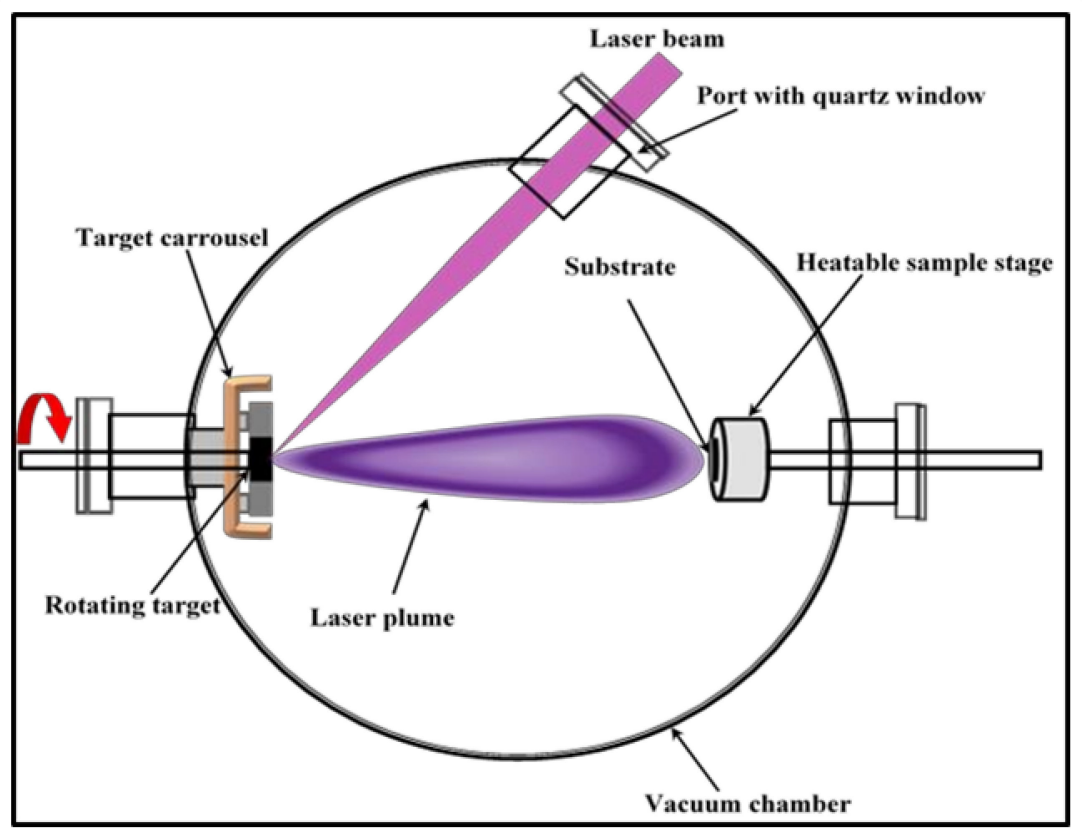

Figure 2. Simplified schematic diagram illustrating the pulsed laser deposition (PLD) set-up.

\subsection{The Evaporation of the Ablated Materials onto the Substrate}

The quality of the thin film, to a large extent, depends on how the ablated species is evaporated onto the substrate. This could be affected by the different laser parameters, such as the laser energy, pulse repetition rate and number of pulses. These laser properties can influence the energy of the ejected species arriving on the substrate [14]. A high plume density can be formed when the average intensity of the laser beam exceeds the ionization threshold of the material [15]. It should be noted that damages could be induced on the substrate at a very high plume density. The interaction mechanisms between the incident plume flux and the substrate involve three steps. These include (i) the sputtering of atoms by energetic incident plume from the surface of the substrate and (ii) the creation of collision region (thermalized region) between the incident plume and the sputtered atoms. The collision region serves as particle condensation source that initiates the final step, i.e., (iii) film growth.

\subsection{The Nucleation and Growth of a Thin Film on the Surface of the Substrate}

During the nucleation and growth stage of the film, there is a transition from the plasma (plume) phase to a crystalline (solid) phase on the substrate surface. Crystalline thin film nucleation and growth depends on several factors, namely the laser energy, pulse repetition rate, density and degree of ionization of the ablated material, substrate temperature, physicochemical properties of the substrate and background pressure. However, the two major thermodynamic parameters involved in the growth mechanism are the substrate temperature $(T s)$ and the supersaturation $(S)$ that takes place between the plasma and solid phase of the material during crystallization. These two parameters are related by Equation (4):

$$
S=k_{B} T_{S} \ln (R / R e)
$$

where $k_{B}$ is the Boltzmann constant, $R$ is the rate of deposition and $R_{e}$ is the equilibrium deposition value at temperature $T$ [16]. Equation (4) shows that supersaturation varies directly with the substrate temperature. A small value of supersaturation is characterized by large nuclei, which lead to creation of dispersed patches (islands) of the films on the surface of the substrate. At this low value of the supersaturation, the interstep distance between the islands increases and in turn the growing surface becomes smooth [17]. As the number of the clusters impinging on the surface of the substrate increases, 
the island density increases [18] and the nucleus of the islands shrinks to the atomic level as the supersaturation increases [16]. For a further increase in the supersaturation value (at high substrate temperature) the islands emerges via coalescence phenomenon (which is liquid-like for some cases) [18]. High supersaturation rate may be required to initiate nucleation. However, a low supersaturation rate is needed at a later stage to facilitate a single crystal film growth [19]. The mean thickness $t$ at which the growing and discontinuous thin film reaches continuity is given by Equation (5):

$$
t=A(1 / R)^{1 / 3} \exp \left(-1 / T_{s}\right)
$$

where $T_{S}$ is the substrate temperature, $R$ is the deposition rate and $A$ is a constant related to the properties of the material [20].

Generally, there are three modes of thin film growth, namely island or the Volmer-Weber mode, layer-by-layer or the Frank-van der Merwe mode and layer plus island or the Stranski-Krastanov mode.

Island or the Volmer-Weber mode: an island growth occurs when the cohesion between the atoms of the target material is greater than the adhesion between the target atoms and the substrate. As a result, the adatoms (atoms deposited on the surface of the substrate) are more bound to each other than to the substrate, hence forming clusters [18]. This mode of growth is characterized by three-dimensional (3D) islands (Figure 3a).

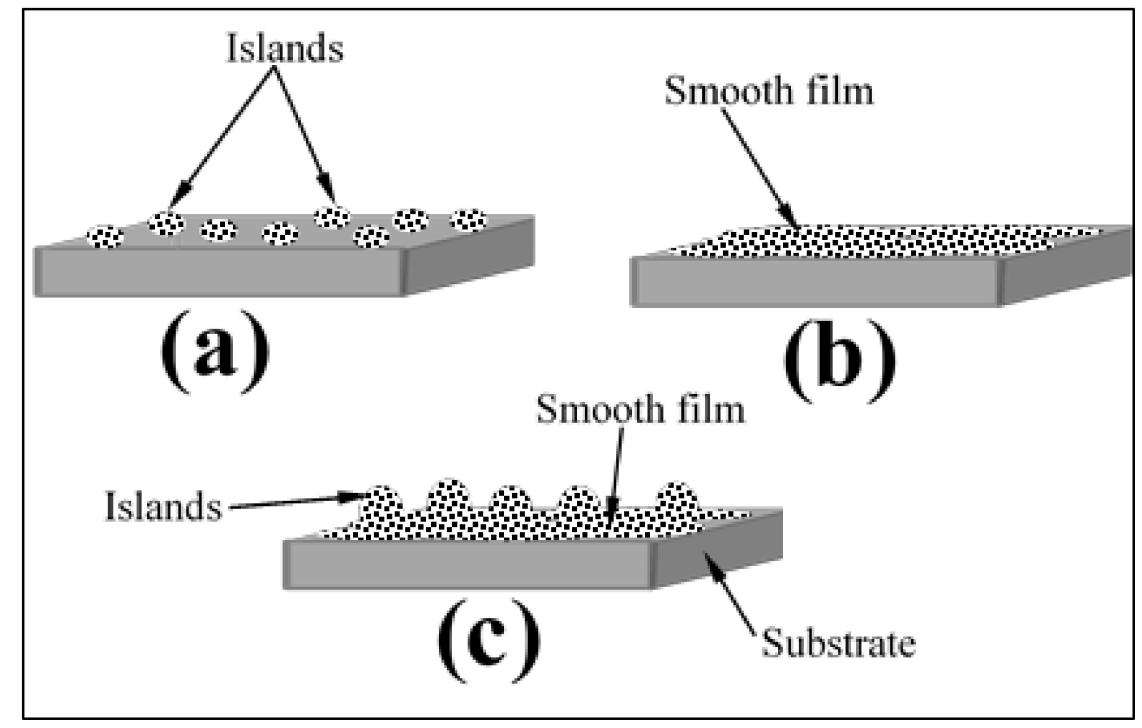

Figure 3. Modes of thin film growth: (a) island (b) layer-by-layer and (c) layer plus island.

Layer-by-layer or the Frank-van der Merwe mode: layer-by-layer growth occurs when the adhesion between the adatoms and the substrate is greater than the cohesion between the adatoms. This mode of growth generally results in 2D growth with the adatoms forming smooth monolayers on the surface of the substrate [21] (Figure 3b).

Layer plus island or the Stranski-Krastanov mode: layer plus the island growth mode occurs when islands are formed after the formation of one or two monolayers on the surface of the substrate (Figure 3c) [18].

\subsection{Advantages and Disadvantages of PLD}

Compared to other PVD techniques such as MBE, EBPVD, arc discharge, ion beam sputtering and reactive sputtering and chemical vapor deposition (CVD) techniques, the PLD technique has shown some outstanding advantages. In CVD, precursors are used as the starting material, while in PLD solid targets are deposited on a substrate using laser ablation. In PLD, the rate of the film growth can be controlled by changing background gas, adjusting the laser parameters, deposition time and 
substrate to target distance [22]. Some of the major advantages of PLD over other PVD techniques are the transfer of the stoichiometry of the target material deposited on the substrate, deposition at high temperature and high deposition rate $[14,23]$. Another advantage of PLD is that a very short time frame is required for deposition.

A major disadvantage of PLD is the non-uniformity of the particulate size across the surface of the film. This non-uniform distribution of particulate size is due to the presence of molten material (up to $10 \mu \mathrm{M}$ ) in the ablated material. Lately, PLD has been modified in different ways to improve the quality of deposited films.

\section{Recently Modified PLD Arrangement}

One of the major drawbacks encountered during deposition of thin films by laser ablation is splashing. Splashing refers to the formation of small melt droplets during ablation, which subsequently land on the substrate. These microsized droplets form islands on the surface of the film. In the last decades, different geometrical configurations have been used in the PLD technique, usually by varying the orientation of the substrate, target and the laser beam side entry with respect to one another [24-28], either to solve the problem of splashing or to generally improve the quality of the deposited film. In a quest to achieve high quality thin films, researchers have continued to modify the geometrical configuration of the PLD set-up as follows:

\subsection{Scanning Multi-Component Pulsed Laser Deposition}

Fischer et al. [29] proposed a "scanning multi-component pulsed laser deposition method" and the set-up they used in their experiment is shown in Figure 4. The multi-component coatings allowed them to deposit single or multilayers onto a substrate through laser induced ablation by horizontal line-scanning of a laser (femto-second laser) beam across a segmented targets. This type of arrangement enabled the deposition of a desired composition of films from the various segments of the target (which contain different materials) by moving the scan line with respect to the target geometry. The advantages of this set-up over the conventional PLD set-up are a large area and uniform deposition of multicomponent coatings.

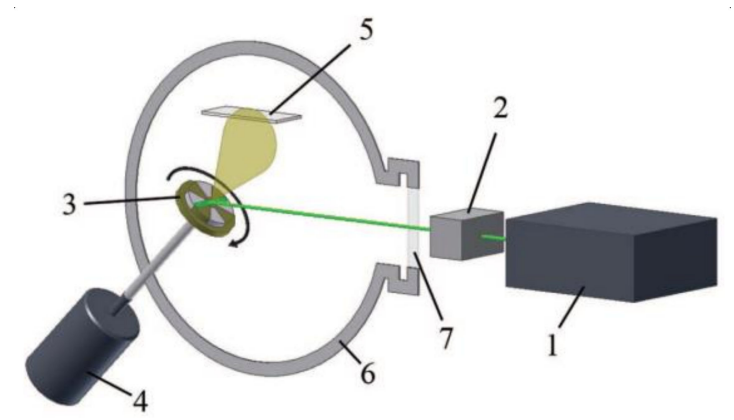

Figure 4. Schematic illustration of the set-up of the scanning multi-component pulsed laser deposition (1: laser, 2: scanner, 3: segmented target, 4: motor, 5: substrate, 6: vacuum chamber and 7: optical window). Printed from [29] with permission.

\subsection{Combined PLD and Magnetron Sputtering}

Benetti et al. [30] demonstrated a thin film deposition system, which combined PLD and magnetron sputtering (MS). The schematic arrangement of the PLD/MS hybrid system is shown in Figure 5. The PLD/MS hybrid system is designed such that the plume generated by pulsed laser on interacting with the target triggers and maintain the magnetron discharge at pressure lower than the standard MS system. The film structure and thickness are influenced by the ionic and neutral species, which are deposited on the substrate after passing through the magnetic field. The major advantage of the combined PLD/MS system over the conventional PLD is the increased deposition rate, which is 
achieved by the increased plasma sputtering rate and direct pulsed laser deposition of clusters and neutral atomic species.

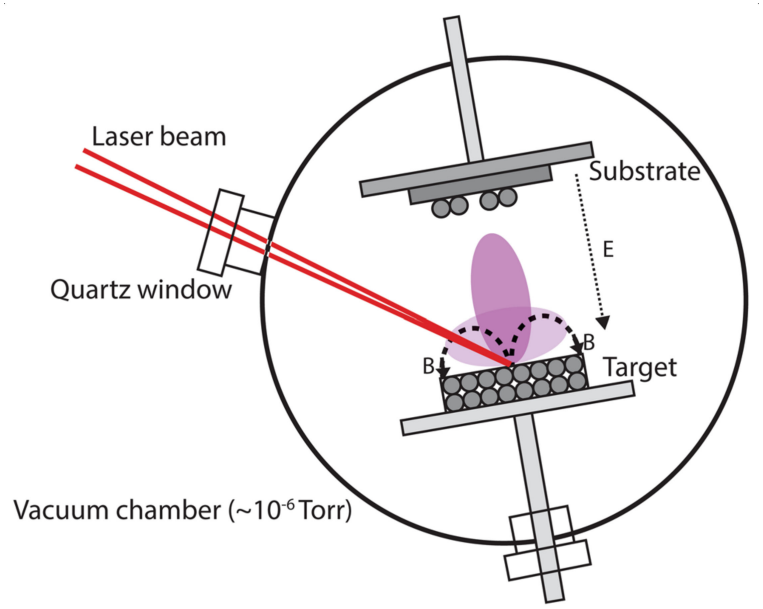

Figure 5. Schematic illustration of the combined pulsed laser deposition and magnetron sputtering system. Printed from [30] with permission.

\subsection{Matrix Assisted Pulsed Laser Evaporation (MAPLE)}

The matrix assisted pulsed laser evaporation (MAPLE) technique has been widely reported for the gentle deposition of inorganic, polymers and biomaterials [31-38]. Yang et al. [39] have published a comprehensive review paper on MAPLE. A schematic diagram illustrating the experimental set-up for MAPLE is shown in Figure 6. Generally, a frozen target is used in MAPLE. The target consists of a polymeric compound (inorganic or biomaterial as the case may be) usually dissolved in a volatile solvent. Upon laser ablation, an ample amount of the laser energy is absorbed by the molecules of the solvent. With this, the molecule of the material is protected from being damaged by the high energy laser beam. The energy absorbed by the solvent molecule heats up the target molecules while the solvent vaporizes [31]. The target molecules are converted to the vapor phase when they have absorbed a substantial amount of energy via collisions with the solvent molecules. The evaporated target molecule is easily deposited on the substrate placed in the opposite direction. The solvent molecules, however, are pumped out by means of the vacuum pump since they have lower adhesion coefficient [32].

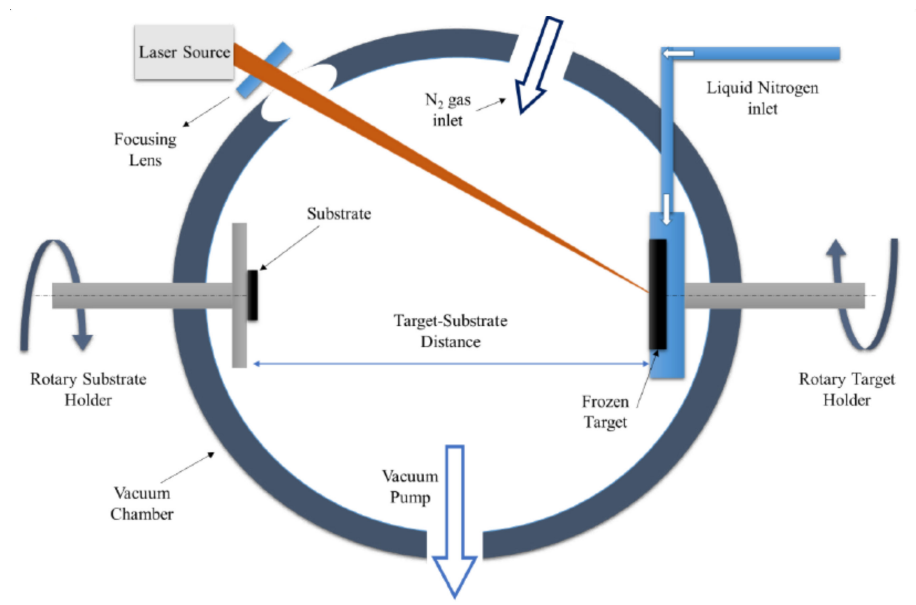

Figure 6. Schematic of the matrix assisted pulsed laser evaporation (MAPLE) experimental set-up. Printed from [39] with permission. 


\subsection{Multi-Beam PLD}

Multi-beam PLD involves a simultaneous deposition of a thin film from a multitarget of dissimilar material by mixing of more than one plume. This is usually achieved by the ablation of different targets with a different laser beam [40,41]. A schematic showing a typical multitarget PLD experimental set-up is presented in Figure 7. It is comprised of three rotatable targets, which can be ablated using three different lasers [42]. The targets also have a programmable tilt capability and adjustable distance from the substrate. The plumes generated by the three lasers can be time-delayed or synchronous, which gives room to control the respective contribution of each target by either adjusting the laser repetition rate or by blocking the laser beam from reaching a given target using a computer automated shutter.

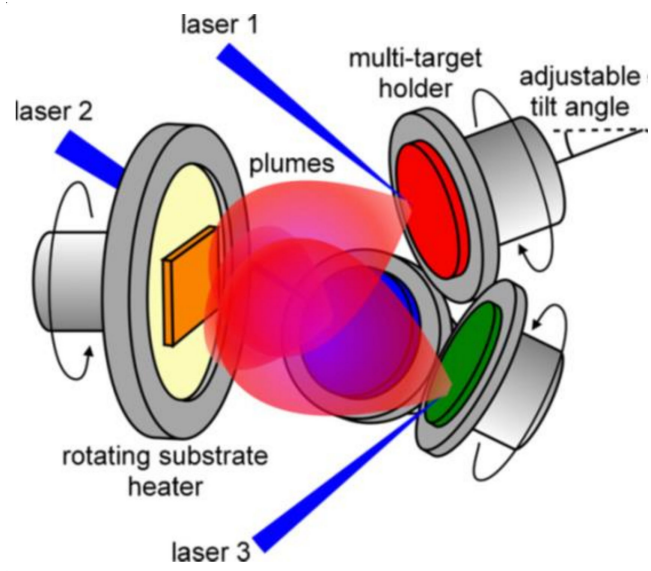

Figure 7. Schematic illustration of multi-beam PLD targets and substrate. Printed from [43] with permission.

\subsection{Off-Axis PLD}

Off-axis PLD arrangement involves placement of the substrate perpendicular to the target (Figure 8), in contrast to the on-axis arrangement (used in the conventional PLD) where the substrate is placed in the opposite direction to the target [44]. Thin films deposited using the off-axis technique have shown superior qualities such as about seven times thinner, $15 \mathrm{~nm}$ compared to $100 \mathrm{~nm}$ obtained from the film deposited using on-axis setup [45] and uniform films with a larger film area, up to 2 inches $(\sim 5 \mathrm{~cm})$ in diameter [46].

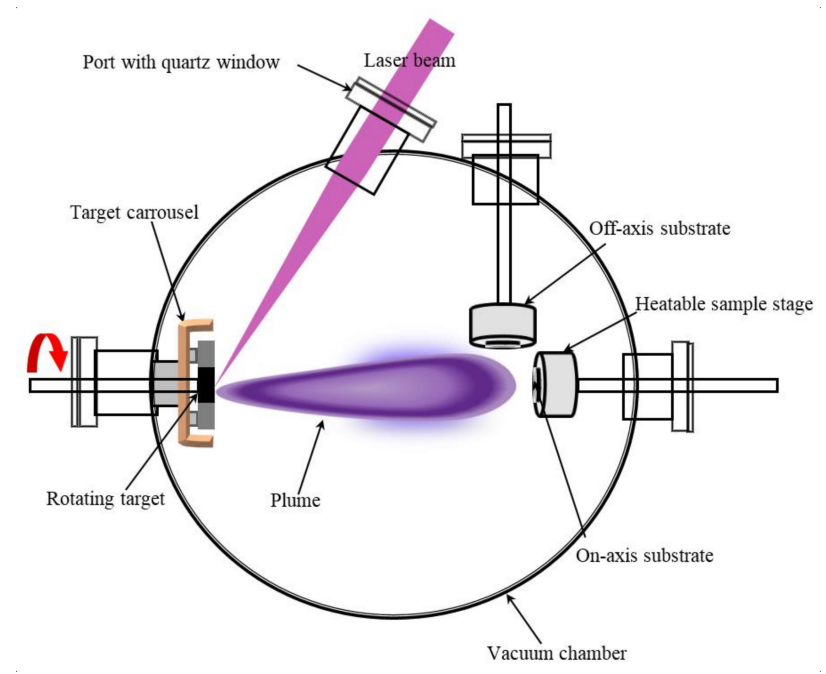

Figure 8. Schematic of the off-axis PLD arrangement. 


\section{Overview of Devices Fabricated Using PLD}

Recently, PLD has been used for the fabrication of different technological devices photovoltaic cells and light emitting diodes (LEDs). Elhmaidi et al. [47] used the PLD to fabricate photovoltaic cell devices based on p-type $\mathrm{Cu}_{2} \mathrm{ZnSnS}_{4}$ (CZTS) layers deposited on n-type silicon nanowires (n-SiNWs). To optimize the photoconversion efficiency of the cells, thin layers of the p-CZTS/n-SiNWs heterojunction devices with CZTS thicknesses ranging from $0.3-10 \mu \mathrm{M}$ and SiNWs lengths ranging from 1-6 $\mu \mathrm{M}$ were fabricated. They achieved a record breaking power conversion efficiency of $5.5 \%$ from the p-CZTS/n-SiNWs heterojunction device with a CZTS thickness of $540 \mathrm{~nm}$ deposited on length SiNWs of $2.2 \mu \mathrm{M}$. Kadhim et al. [48] used PLD to develop a solar cell device based on CdTe/CdS thin film. The thickness of the films varied from 1.5 to $0.75 \mu \mathrm{M}$. They reported a power conversion efficiency of $5.3 \%$ from the film with the thinnest layer of $0.75 \mu \mathrm{M}$. Beloso et al. [49] fabricated electrostimulator by depositing the aluminum thin film on a soda-lime glass substrate. This technique involves selective removal of the deposited aluminum layer with a $15 \mu \mathrm{M}$ beam spot size laser. Wang et al. [50] published an interesting review on photodetector devices developed using the PLD technique.

Recently, LEDs of different luminescence materials have been fabricated using the PLD technique. Sarkar et al. [51] reported a white light emission from CdS/p + -black Si (CdS/p + -bSi) LED, manufactured by laser ablation of $\mathrm{n}-\mathrm{CdS}$ thin film on a nanoporous $\mathrm{Si}$ nanocones fabricated subsequently by means of metal-assisted chemical etching technique. A detailed review of this publication is in Section 5. Kim et al. [52] produced an LED device based on $\mathrm{ZnO}$ thin film fabricated on a sapphire substrate. They obtained a diode characteristic of $2.2 \mathrm{eV}$ turn-on voltage from a $\mathrm{ZnO}: \mathrm{P} / \mathrm{Zn}_{0.9} \mathrm{Mg}_{0.1} \mathrm{O} / \mathrm{ZnO} / \mathrm{Zn}_{0.9} \mathrm{Mg}_{0.1} \mathrm{O} / \mathrm{ZnO}$ :Ga heterojunction diode. The electroluminescence (EL) spectrum of the film was characterized by an ultraviolet and a deep level emission. Bayram et al. [53] reported a PLD grown $n-\mathrm{ZnO} /(\mathrm{InGaN} / \mathrm{GaN})$ multi-quantum-wells/p-GaN green emitting LEDs. They grew the film on a semi-insulating AIN/sapphire. The LEDs showed a characteristic turn-on voltage of $2.5 \mathrm{~V}$ and the EL spectrum measured at room temperature showed a maximum around $510 \mathrm{~nm}$. Cheng et al. [54] published $\mathrm{n}-\mathrm{Zn}_{1-\mathrm{x}} \mathrm{Cd} \mathrm{x} / \mathrm{p}-\mathrm{GaN}$ heterojunction $\mathrm{LED}$ with tunable color. The films were grown on c-sapphire and p-GaN substrates. By increasing the concentration of $\mathrm{Cd}$, the color emitted by the LEDs changes from blue to green. Su et al. [55] reported white light emitting n-ZnO/p-GaN heterojunction LEDs. The characteristic turn-on voltage of the LED device was reported to be $3.5 \mathrm{~V}$. Huang et al. [56] published a tunable color heterojunction LEDs based on $n-\mathrm{ZnO} / \mathrm{CsPbBr} 3 / \mathrm{p}-\mathrm{GaN}$ layers. The EL spectra of the LEDs changed from violet to greenish-yellow as the thickness of the $\mathrm{CsPbBr}_{3}$ layer was varied. The introduction of the $\mathrm{CsPbBr}_{3}$ layer increased the turn-on voltage of the heterojunction LED from 3.7 to $5.0 \mathrm{~V}$. The EL showed a narrow violet emission around $420 \mathrm{~nm}$ originating from the p-GaN layer and a broad deep emission band from ZnO. Zhang et al. [57] reported LEDs based on $\mathrm{n}-\mathrm{ZnO}: \mathrm{Ga} / \mathrm{i}-\mathrm{ZnO} / \mathrm{p}-\mathrm{GaN}: \mathrm{Mg}$ heterojunction fabricated on a sapphire substrate. The turn-on voltage of the LEDs increased from 2.5 to $5.0 \mathrm{~V}$ after the incorporation of the $\mathrm{i}-\mathrm{ZnO}$ layer. The EL spectrum of the $\mathrm{n}-\mathrm{ZnO}: \mathrm{Ga} / \mathrm{p}-\mathrm{GaN}$ heterojunction exhibited a bluish-violet emission with a maximum around $425 \mathrm{~nm}$, while the heterojunction incorporated with $\mathrm{i}-\mathrm{ZnO}(\mathrm{n}-\mathrm{ZnO}: \mathrm{Ga} / \mathrm{i}-\mathrm{ZnO} / \mathrm{p}-\mathrm{GaN})$ exhibited EL spectrum with bands centering at 386 and $424 \mathrm{~nm}$. The bands at 386 and 424 (425) nm originated from $\mathrm{ZnO}$ and p-GaN layers, respectively.

\section{Experimental Procedure}

An example of the experimental procedure for PLD thin film preparation will be discussed in this section. A simplified conventional PLD set-up has been shown earlier in Figure 2, it comprises of a vacuum chamber, a laser beam, sample and the target stage. As previously stated, the target is usually irradiated at an angle between 45 and $60^{\circ}$. Common substrate materials usually used in PLD are yttrium stabilized zirconium oxide (YSZ), strontium titanate $\left(\mathrm{SrTiO}_{3}\right)$ [58], magnesium oxide $(\mathrm{MgO})$ and sapphire $\left(\mathrm{Al}_{2} \mathrm{O}_{3}\right)[59,60]$. Some semiconductors such as silicon $(\mathrm{Si})$, gallium oxide $\left(\beta-\mathrm{Ga}_{2} \mathrm{O}_{3}\right)[61]$, fused silica $\left(\mathrm{SiO}_{2}\right)$ [62], zinc oxide $(\mathrm{ZnO})$ and gallium arsenide $(\mathrm{GaAs})$ [60] have also been used as substrates. For a high temperature deposition, substrate material that can match such temperature 
should be chosen. The substrate is usually positioned parallel and opposite to the target in a conventional PLD set-up with a variable substrate to target distance. The deposition chamber is commonly pumped down to around $10^{-6}$ Torr. Background gases such as argon (Ar), oxygen $\left(\mathrm{O}_{2}\right)$, nitrogen oxide $\left(\mathrm{N}_{2} \mathrm{O}\right)$, nitrogen $\left(\mathrm{N}_{2}\right)$ or other gases may be pumped through the chamber to slow down the plume during deposition. In some cases, thin film can be deposited in the vacuum by introducing any gas into the chamber. The laser parameters can be varied. Depending on the wavelength of the laser used, the laser energy can be as low as $40 \mathrm{~mJ}[63,64$ ] or as high as 200-300 $\mathrm{mJ}$ [59]. With these laser energies, a repetition rate of 10-50 Hz, deposition time of 15-55 min and film of thickness between 150 and $500 \mathrm{~nm}$ can be grown $[63,64]$.

\section{Structure, Morphologies and Luminescence of Thin Films Deposited Using PLD}

The field emission scanning electron microscope (FESEM) cross-section image of the bSi fabricated on a Si substrate reported by Sarkar et al. [51] is shown in Figure 9a. The FESEM micrograph revealed that the bSi formed vertical cone-shaped nanostructures of the diameter between 500 and $700 \mathrm{~nm}$, height between 1 and $3 \mu \mathrm{M}$ and tips of a few nanometers in diameter. The transmission electron microscope (TEM; Figure $9 \mathrm{~b}$ ) of the cross-section of the Si nanostructure revealed the nanocones shape. The porous structure of the Si nanocones at the surface of the cone resulting from the chemical etching is shown in the inset of Figure 9b. The selective area electron diffraction (SAED) pattern (Figure 9c) confirmed that the core of the nanocones were crystalline despite the pore $(2-5 \mathrm{~nm})$ observed at the outer shell. The cross-section of the FESEM image of the CdS thin film laser ablated on a bSi nanocones is shown in Figure 9d. The FESEM micrograph confirmed a uniform coverage of CdS thin film with thickness between 50 and $80 \mathrm{~nm}$ on the surface of the bSi nanocones. The thickness of some thin films recently deposited using PLD is summarized in Table 1 . The uniformity of the CdS layer on the surface of the nanocones is further confirmed by the FESEM image shown in Figure 9e. As shown in Figure $9 \mathrm{f}$, the SAED pattern of the CdS/bSi heterojunction shows the diffraction rings confirming the polycrystalline nature of the CdS thin film. The SAED pattern also revealed the (002), (110) and (112) planes of wurtzite CdS [51].

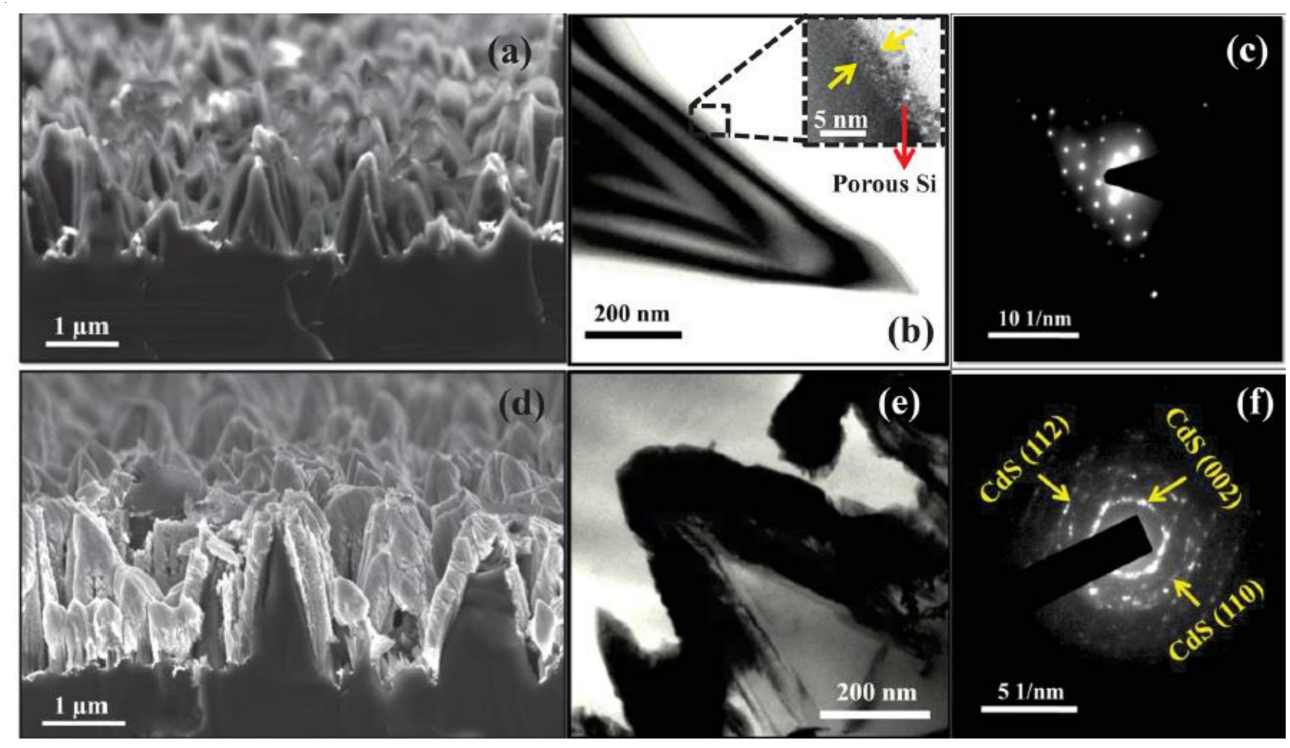

Figure 9. (a) Cross-sectional FESEM image of Si nanocone (bSi) arrays, (b) high-resolution TEM image of a single Si nanocone, (c) SAED pattern from Si nanocone, (d) cross-sectional FESEM image of CdS/bSi conical-heterojunction arrays, (e) high-resolution TEM image of a single CdS/bSi nanocone conical heterojunction and an (f) SAED pattern from the CdS/bSi nanocone heterostructure. Printed from [51] with permission. 
Table 1. Film thicknesses, laser parameters and other variable parameters of PLD deposited thin films.

\begin{tabular}{|c|c|c|c|c|c|c|c|}
\hline Material & Substrate & $\begin{array}{l}\text { Laser/Laser } \\
\text { Parameters }\end{array}$ & $\begin{array}{l}\text { Deposition } \\
\text { Time (m) }\end{array}$ & $\begin{array}{l}\text { Deposition } \\
\text { Atmosphere }\end{array}$ & $\begin{array}{c}\text { Substrate } \\
\text { Temperature }\left({ }^{\circ} \mathrm{C}\right)\end{array}$ & $\begin{array}{l}\text { Thickness } \\
\text { (nm) }\end{array}$ & Ref \\
\hline $\mathrm{CdS} / \mathrm{p} \pm \mathrm{bSi})$ & Si (100) & Nd:YAG, $\lambda=$ & - & - & - & 50,80 & [51] \\
\hline $\mathrm{ZnO} / \mathrm{MgZnO}$ & sapphire & $\begin{array}{c}\mathrm{RR}=10 \\
\mathrm{LF}=1-2 \\
\mathrm{PW}=8 \\
\mathrm{Nd}: \mathrm{YAG} \\
\lambda=355\end{array}$ & - & - & $800,700,650$ & $\begin{array}{l}8,5,100 \\
450\end{array}$ & [65] \\
\hline $\mathrm{Cu}_{2} \mathrm{ZnSnS}_{4}$ & $\mathrm{Si}$ & $\begin{array}{c}\mathrm{RR}=10 \\
\mathrm{LF}=0.5-4 \\
\mathrm{PW}=4.7 \\
\mathrm{KrF} \text { excimer } \\
\lambda=248\end{array}$ & 45 & - & 300 & 50 & [66] \\
\hline ITO, AZO, & PET & $\begin{array}{c}\mathrm{RR}=10 \\
\mathrm{LF}=1 \\
\mathrm{PW}=30 \\
\text { KrF excimer }\end{array}$ & - & - & $25-125$ & 100, 200 & [67] \\
\hline $\mathrm{ZnO}: \mathrm{Cu}$ & $\mathrm{Si}$ & $\begin{array}{c}\text { KrF excimer } \\
\lambda=248 \\
\mathrm{RR}=2 \\
\mathrm{LE}=400\end{array}$ & - & vacuum & - & 40,300 & [68] \\
\hline $\mathrm{ZnO}: \mathrm{Zn}$ & Si (100) & $\begin{array}{c}\text { Nd:YAG } \\
\lambda=266 \\
\text { RR }=10 \\
\text { LE }=40 \\
\text { Nd:YAG }\end{array}$ & 25 & $\begin{array}{c}\text { vacuum, } \\
\mathrm{Ar}, \mathrm{O}_{2}\end{array}$ & 300 & $\begin{array}{l}80,155 \\
285\end{array}$ & [69] \\
\hline $\mathrm{ZnO}: \mathrm{Zn}$ & Si (100) & $\begin{array}{l}\lambda=266 \\
R R=10 \\
L F=0.8 \\
P W=8\end{array}$ & 25 & $\mathrm{O}_{2}$ & $50,200,400$ & $\begin{array}{c}246,414 \\
326\end{array}$ & [70] \\
\hline $\mathrm{In}_{2} \mathrm{Se}_{3}$ & $\begin{array}{l}\text { transparent } \\
\text { polyimide }\end{array}$ & $\begin{array}{c}\text { KrF excimer } \\
\lambda=248 \\
R R=4 \\
\text { LE }=100 \\
P W=20 \\
\text { Nd:YAG }\end{array}$ & 12.5 & $\mathrm{O}_{2}$ & 300 & 22.9 & [71] \\
\hline $\mathrm{Ga}_{2} \mathrm{O}_{3}$ & $\mathrm{Si}(100)$ & $\begin{array}{l}\Lambda=266 \\
R R=50 \\
L E=40\end{array}$ & 15 & $\begin{array}{c}\text { vacuum, } \\
\mathrm{Ar}, \mathrm{O}_{2}\end{array}$ & $50-600$ & 150 & [63] \\
\hline $\mathrm{ZnO}: \mathrm{Tb}^{3+}$ & $\mathrm{Si}(100)$ & $\begin{array}{c}\text { Nd:YAG } \\
\lambda=266 \\
\text { LE }=40 \\
\text { Nd:YAG }\end{array}$ & $15-55$ & $\mathrm{O}_{2}$ & 300 & $150-500$ & [64] \\
\hline $\mathrm{Y}_{3}(\mathrm{Al}, \mathrm{Ga})_{5} \mathrm{O}_{12}: \mathrm{Ce}^{3+}$ & $\mathrm{Si}(100)$ & $\begin{array}{l}\lambda=266 \\
R R=10 \\
L F=0.8\end{array}$ & - & $\begin{array}{c}\text { Vacuum, } \\
\mathrm{Ar}\end{array}$ & 300 & 120,270 & [72] \\
\hline$\beta-\left(\mathrm{Al}_{\mathrm{x}} \mathrm{Ga}_{1-\mathrm{x}}\right)_{2} \mathrm{O}_{3}$ & $\begin{array}{c}\beta-\mathrm{Ga}_{2} \mathrm{O}_{3} \\
(010)\end{array}$ & $\begin{array}{c}\text { KrF excimer } \\
\lambda=248 \\
\mathrm{RR}=10 \\
\mathrm{LF}=0.3\end{array}$ & - & $\mathrm{O}_{2}$ & 800 & 70,79 & [61] \\
\hline$\beta-\mathrm{Ga}_{2} \mathrm{O}_{3}$ & sapphire & $\begin{array}{l}\text { KrF excimer } \\
\lambda=248 \\
\mathrm{LF}=2\end{array}$ & - & $\mathrm{O}_{2}$ & 650 & $\begin{array}{l}250,350 \\
500\end{array}$ & [73] \\
\hline $\mathrm{Ga}_{2} \mathrm{O}_{3}: \mathrm{Sn}$ & sapphire & $\begin{array}{c}\mathrm{RR}=3 \\
\mathrm{LF}=2 \\
\mathrm{Nd}: \mathrm{YAG} \\
\lambda=266\end{array}$ & - & $\mathrm{O}_{2}$ & 650 & $\begin{array}{l}112,445 \\
510,570\end{array}$ & [74] \\
\hline $\mathrm{CaS}: \mathrm{Eu}^{2+}$ & $\mathrm{Si}(100)$ & $\begin{array}{c}355,532, \mathrm{RR}= \\
10 \\
\mathrm{LF}=5.09 \\
\mathrm{LE}=40\end{array}$ & - & $\mathrm{Ar}$ & 400 & $150,162,23$ & [75] \\
\hline
\end{tabular}

$\lambda=$ wavelength $(\mathrm{nm}), \mathrm{RR}=$ repetition rate $(\mathrm{Hz}), \mathrm{LF}=$ laser fluence $\left(\mathrm{J} \mathrm{cm}^{-2}\right), \mathrm{PW}=$ pulse width $(\mathrm{ns})$, $\mathrm{LE}=$ laser energy $(\mathrm{mJ})$.

Figure 10 shows the FESEM images of $\mathrm{Ga}_{2} \mathrm{O}_{3}$ thin films we reported in our recent work [63]. The films were deposited at different substrate temperatures (room temperature, 100, 200, 300, 400, 500 and $600{ }^{\circ} \mathrm{C}$ ) and the images are shown in Figure $10 \mathrm{a}-\mathrm{g}$ respectively. We observed that the morphology of the particles was temperature dependent, with the films deposited at lower temperatures comprising of an agglomeration of spherically shaped nanoparticles while the films deposited at a higher substrate 
temperature were composed mainly of cubic shaped nanoparticles. The formation of nanocubes is due to preferential crystal plane orientation over others during the growth of the films [76,77]. These variations in the particle morphologies resulted in a significant variation of the shapes of the photoluminescence (PL) spectra depicted in the 13th figure.

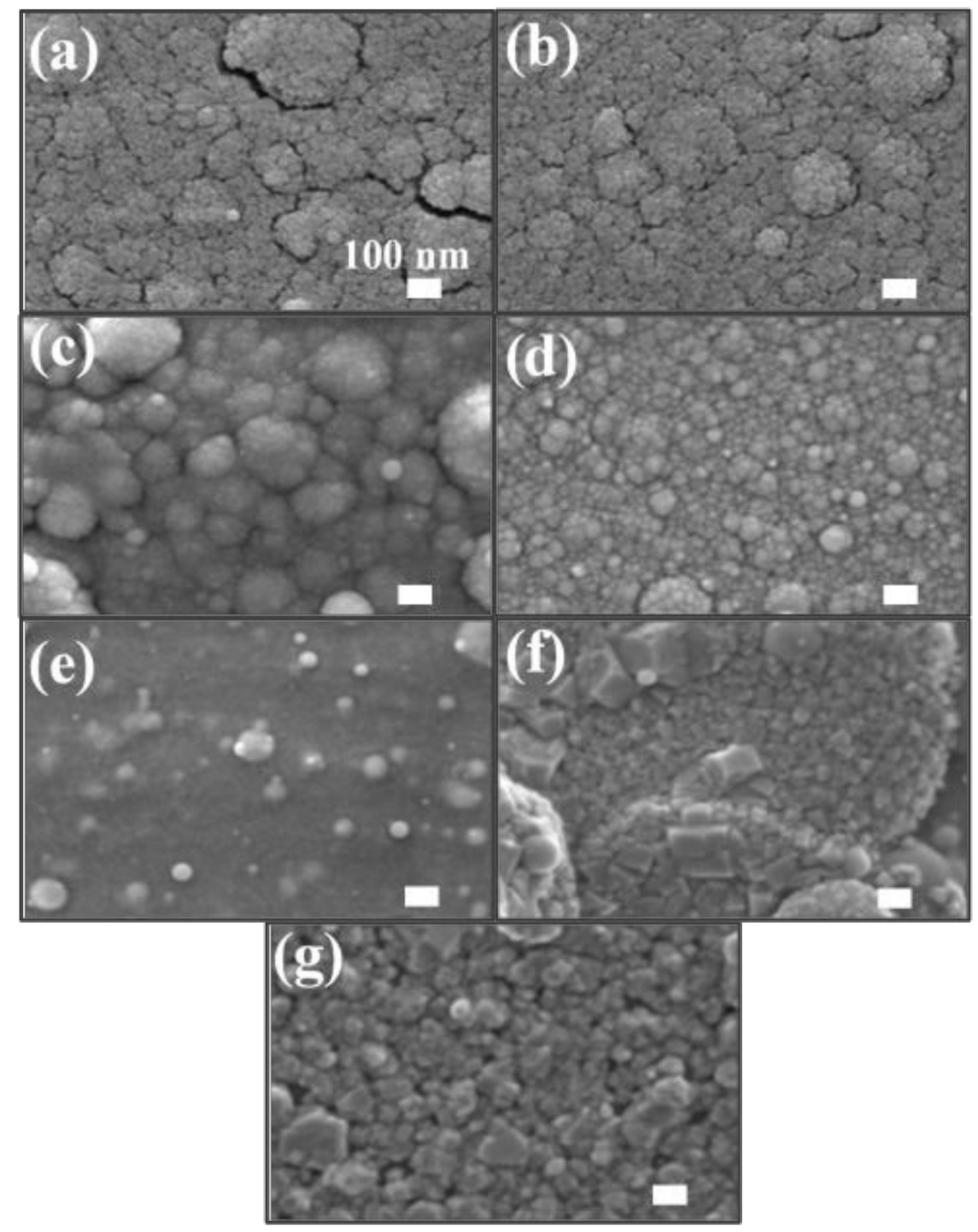

Figure 10. FESEM images of $\mathrm{Ga}_{2} \mathrm{O}_{3}$ films deposited at (a) room temperature, (b) 100, (c) 200, (d) 300, (e) 400, (f) 500 and (g) $600{ }^{\circ} \mathrm{C}$. All scale bars are $100 \mathrm{~nm}$. Printed from [63] with permission.

Figure 11a shows the normalized PL spectra of the bSi, a control CdS thin film and the CdS/bSi heterojunction excited at the wavelength of $325 \mathrm{~nm}$ [51]. The PL spectrum of the bSi exhibited a broad band with a maxima around $644 \mathrm{~nm}$ assigned to the quantum confinement of the charge carriers present in Si nanocrystals formed on the porous surface area of the bSi nanocones [78-81]. The control CdS thin film showed a sharp peak around $512 \mathrm{~nm}$ assigned to the near band edge (NBE) emission from CdS $[82,83]$ and the broad band with maxima at $714 \mathrm{~nm}$, which is assigned to the transition of trapped electrons from $\mathrm{Cd}$ vacancies to the $\mathrm{CdS}$ valence band $[73,84,85]$. The emission spectra from the CdS/bSi nanocones heterojunction comprises of bands from both Si nanocones and CdS thin film. The deconvoluted PL spectrum of the $\mathrm{CdS} / \mathrm{bSi}$ heterojunction shows three peaks with maxima at 512, 644 and $714 \mathrm{~nm}$ as shown in Figure 11b, which are in agreement with the peak positions of the individual peaks obtained from the PL spectra of Si nanocones and CdS films depicted in Figure 11a. 

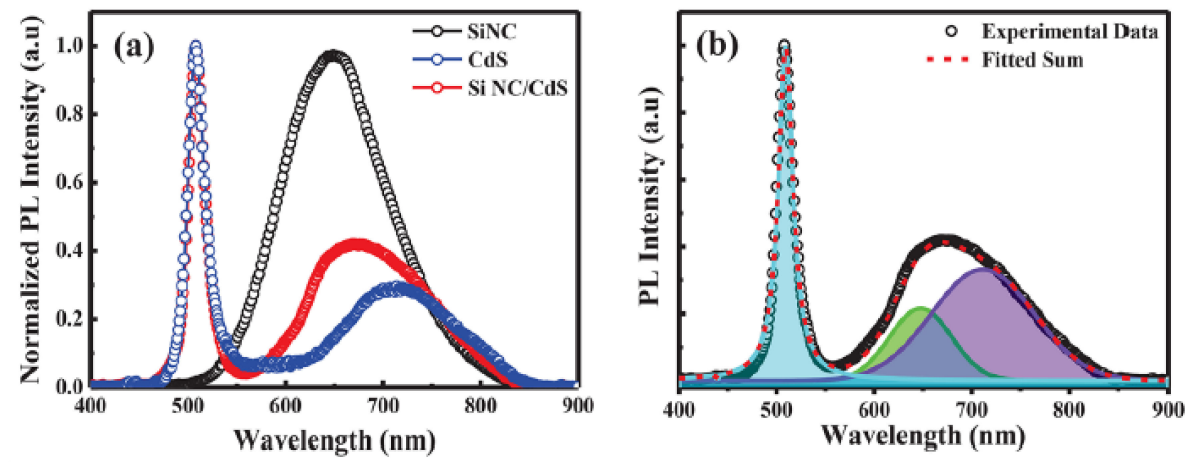

Figure 11. (a) Normalized room-temperature photoluminescence (PL) spectra of bSi and CdS film on c-Si substrate and CdS/bSi conical-heterojunction arrays. (b) Deconvoluted room-temperature PL spectrum of CdS/bSi heterojunction. Printed from [51] with permission.

The EL emission spectra of the n-CdS/p \pm bSi heterojunction at different forward bias voltage $(5-30 \mathrm{~V})$ are depicted in Figure 12a [51]. The EL spectra exhibit broad bands covering almost the entire visible wavelengths and some part of the near-infrared (NIR) region. The inset of Figure 12a is the digital image of the EL emission of the device when a forward bias voltage of $15 \mathrm{~V}$ was applied. The deconvoluted EL emission spectra of the $\mathrm{n}-\mathrm{CdS} / \mathrm{p} \pm \mathrm{bSi}$ heterojunction when applying a $10 \mathrm{~V}$ bias (Figure 12b) exhibited three bands with a maxima at 530, 652 and $735 \mathrm{~nm}$, which were in good agreement with the deconvoluted PL emission spectrum shown in Figure 11b. The integrated EL intensity of the fabricated $\mathrm{n}-\mathrm{CdS} / \mathrm{p} \pm \mathrm{bSi}$ heterojunction (Figure 12c) showed almost a linear behavior with increasing bias voltage from 5 to $15 \mathrm{~V}$ and later showed a saturation tendency. The Commission Internationale de I'Eclairage (CIE) chromaticity coordinate of the $n-C d S / p \pm b S i$ heterojunction calculated from the EL data obtained when $15 \mathrm{~V}$ bias was applied is shown in Figure 12d. The chromaticity coordinates of $\mathrm{x}=0.35$ and $\mathrm{y}=0.41$ suggests a yellowish white emission.
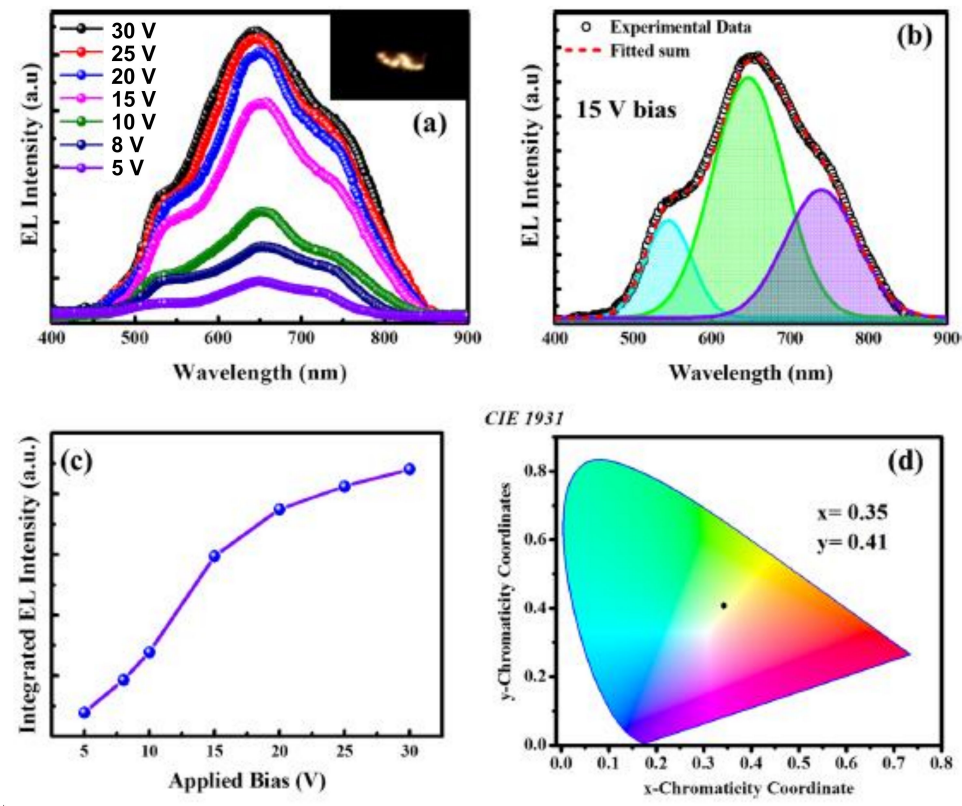

Figure 12. (a) Room-temperature electroluminescence (EL) spectra of an n-CdS/p \pm bSi conical heterojunction at different forward biases. The inset is a photograph of the EL emission at $15 \mathrm{~V}$ forward bias. (b) The deconvoluted EL spectrum of $n-C d S / p \pm b S i$ conical heterojunction arrays under $15 \mathrm{~V}$ forward bias at room temperature. (c) Integrated EL intensity plotted with respect to different applied forward bias. (d) The Commission Internationale de I'Eclairage (CIE) of the data of the n-CdS/p \pm bSi obtained under $15 \mathrm{~V}$ forward bias. Printed from [51] with permission. 
Figure 13 shows the PL emission spectra associated with the $\mathrm{Ga}_{2} \mathrm{O}_{3}$ films whose FESEM images are presented in Figure 10. The spectra were recorded when the films where excited using a $325 \mathrm{~nm}$ $\mathrm{He}-\mathrm{Cd}$ laser. The PL emission spectra in Figure 13a-g are of the $\mathrm{Ga}_{2} \mathrm{O}_{3}$ thin films deposited at different substrate temperatures, namely room temperature, 100, 200, 300, 400, 500 and $600{ }^{\circ} \mathrm{C}$, respectively, as reported by Ogugua et al. [63]. The PL emission spectra showed temperature dependent behavior (like the FESEM micrographs (see Figure 10)) with peaks in the UV, blue, green and red region of the spectrum. The positions of the fitted PL peaks observed at the different substrate temperatures are shown in Table 2. These emission peaks were ascribed to the self-trapped excitons [86], defect donor recombination levels created by oxygen vacancies and the hole in the acceptor level formed by gallium vacancies or gallium-oxygen vacancy pair $[87,88]$ and the presence of impurities such as $\mathrm{Li}, \mathrm{Zr}, \mathrm{Be}, \mathrm{Ge}$, Si and Sn [87], respectively. Figure 13h shows the behavior of the PL emission intensities of the films as a function of substrate temperature.
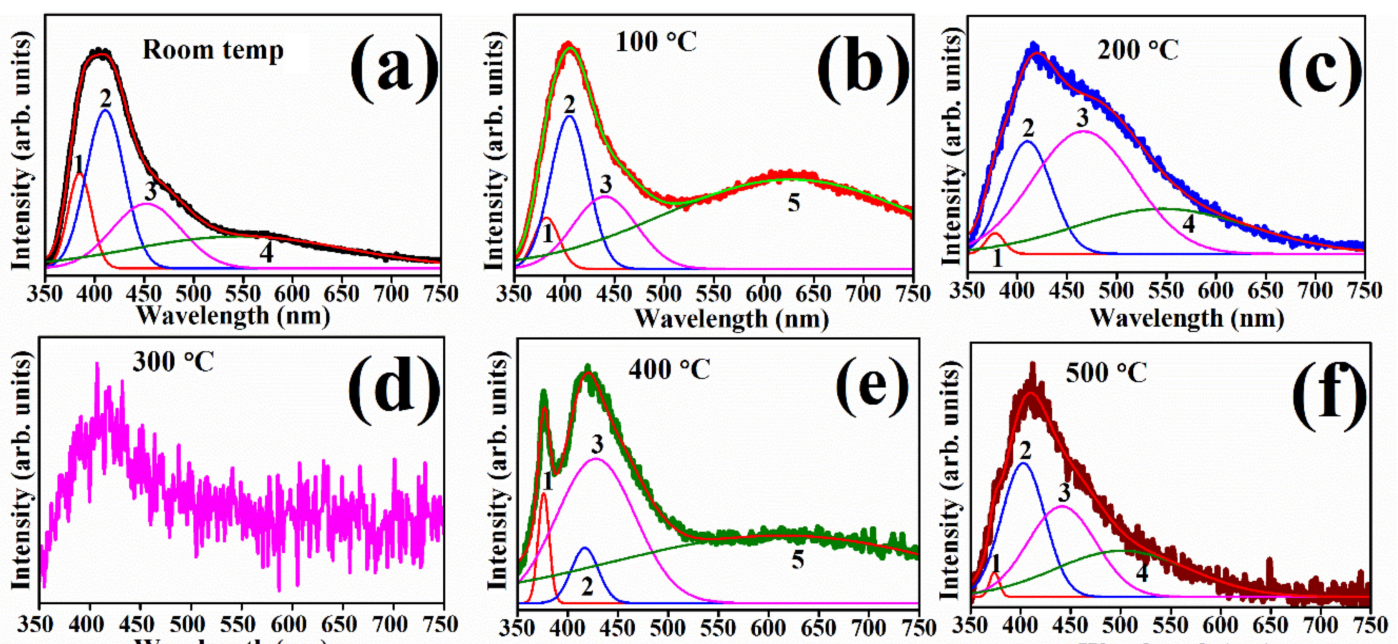

Wavelength $(\mathrm{nm})$

Wavelength $(\mathrm{nm})$

Wavelength $(\mathbf{n m})$
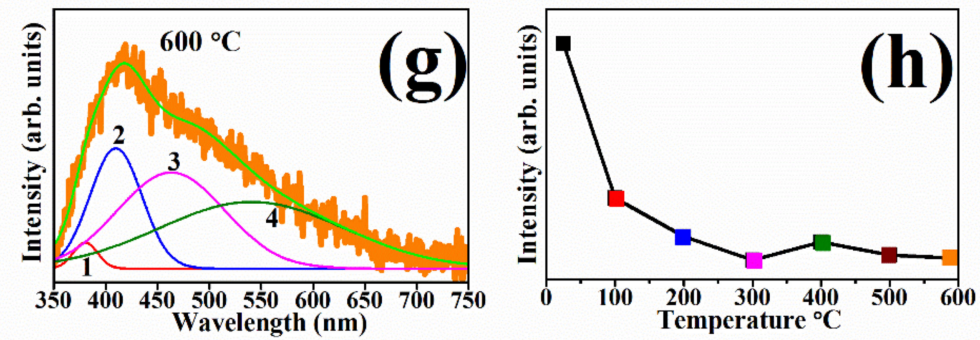

Figure 13. The $\mathrm{PL}$ of $\mathrm{Ga}_{2} \mathrm{O}_{3}$ thin films deposited in $\mathrm{O}_{2}$ atmosphere for $15 \mathrm{~min}$ at (a) room temperature, (b) $100{ }^{\circ} \mathrm{C}$, (c) $200{ }^{\circ} \mathrm{C}$, (d) $300{ }^{\circ} \mathrm{C}$, (e) $400{ }^{\circ} \mathrm{C}$, (f) $500{ }^{\circ} \mathrm{C}$ and (g) $600{ }^{\circ} \mathrm{C}$ excited using $325 \mathrm{~nm}$ He-Cd laser. (h) Maximum intensity as function of temperature. Printed from [63] with permission.

Table 2. The positions of the fitted PL peaks observed at different substrate temperatures as above in Figure 13 [63].

\begin{tabular}{cccccc}
\hline \multirow{2}{*}{ Substrate Temperatures $\left({ }^{\circ} \mathbf{C}\right)$} & \multicolumn{5}{c}{ Peak Positions (nm/eV) } \\
\cline { 2 - 6 } & $\mathbf{1}$ & $\mathbf{2}$ & $\mathbf{3}$ & $\mathbf{4}$ & $\mathbf{5}$ \\
\hline Room Temperature & $385 / 3.22$ & $410 / 3.02$ & $454 / 2.73$ & $575 / 2.16$ & - \\
100 & $383 / 3.24$ & $404 / 3.07$ & $440 / 2.82$ & - & $630 / 1.97$ \\
200 & $376 / 3.30$ & $410 / 3.02$ & $466 / 2.66$ & $555 / 2.23$ & - \\
300 & - & - & - & - & - \\
400 & $376 / 3.30$ & $417 / 2.97$ & $429 / 2.89$ & - & $630 / 1.97$ \\
500 & $376 / 3.30$ & $404 / 3.07$ & $440 / 2.82$ & $510 / 2.43$ & - \\
600 & $378 / 3.28$ & $410 / 3.02$ & $464 / 2.67$ & $544 / 2.28$ & - \\
\hline
\end{tabular}


Other researchers have reported luminescence of different materials deposited using the PLD technique. Kim et al. [52] reported the PL and EL spectra of PLD deposited ZnO. Their PL of the film excited using a $325 \mathrm{~nm}$ He-Cd laser with a maximum emission at $375 \mathrm{~nm}$. The EL recorded using a bias of $7 \mathrm{~V}$ showed emission peak with a maximum at $385 \mathrm{~nm}$. Both the PL and the EL emissions were assigned to the near-band-edge emission of $\mathrm{ZnO}$ [52]. Tetsuyama et al. [89] deposited $\mathrm{ZnO}$ on the p-GaN substrate and the PL spectrum recorded using a $325 \mathrm{~nm}$ He-Cd laser showed the near-band-edge emission at $380 \mathrm{~nm}$ and a broad visible emission with a maximum around $525 \mathrm{~nm}$ attributed to oxygen vacancies [89]. Novoa-De León et al. [90] reported the PL of nitrogen-doped graphene quantum dots with an excitation wavelength assigned to the $\pi \rightarrow \pi^{*}$ transition at $410 \mathrm{~nm}$ and emission wavelength with a maximum at $486 \mathrm{~nm}$ assigned to the $\mathrm{n} \rightarrow \pi^{*}$ transition. Caballero-Briones et al. [91] prepared carbon thin films and measured the PL using a $325 \mathrm{~nm} \mathrm{He}-\mathrm{Cd}$ laser.

The PL emission of the carbon film showed a broad spectrum with peaks at 482, 525 and $634 \mathrm{~nm}$ and maximum at $577 \mathrm{~nm}$ assigned to the radiative recombination in band-tail states created by $\mathrm{sp}^{2}$ clusters. Yamada et al. [92] reported the PL of Si nanocrystallite deposited on a Si substrate covered with $\mathrm{In}_{2} \mathrm{O}_{3}$ thin film, while Kim et al. [67] reported the PL of tin indium oxide (TIO) and aluminum doped zinc oxide (AZO) deposited on a flexible substrate, and Johnson et al. [93] reported the PL of poly [2-methoxy-5-(2-ethylhexyloxy)-1,4-phenylenevinylene] (MEH-PPV) deposited into ITO/MEH-PPV/Al. Table 3 presents some other thin film materials recently prepared using PLD and their PL characteristics.

Table 3. PL data of some recent material prepared using PLD.

\begin{tabular}{|c|c|c|c|c|c|}
\hline Material & $\begin{array}{c}\text { Excitation } \\
\text { Wavelength }(\mathrm{nm})\end{array}$ & $\begin{array}{l}\text { Source(s) of } \\
\text { Excitation }\end{array}$ & $\begin{array}{c}\text { Emission } \\
\text { Wavelength(s) (nm) }\end{array}$ & Source(s) of Emission & Ref. \\
\hline $\mathrm{ZnO}: \mathrm{Zn}$ & 325 & - & 514 & Oxygen vacancies & [94] \\
\hline $\mathrm{ZnO}: \mathrm{Zn}$ & 325 & - & $\begin{array}{c}379,405-450,500-550 \\
600,624,658\end{array}$ & $\begin{array}{l}\text { Exciton recombination, } \\
\text { zinc vacancies, oxygen } \\
\text { vacancies, oxygen } \\
\text { interstitial, reduction of } \\
\text { oxygen vacancies }\end{array}$ & [69] \\
\hline $\mathrm{ZnO}: \mathrm{Zn}$ & 325 & - & $378,449,550,600$ & $\begin{array}{l}\text { Exciton recombination, } \\
\text { zinc vacancy, oxygen } \\
\text { vacancies, oxygen } \\
\text { interstitials }\end{array}$ & [70] \\
\hline $\mathrm{TiO}_{2}$ & - & - & $380-415$ & Near-band-edge & [95] \\
\hline $\begin{array}{c}\mathrm{Y}_{3}(\mathrm{Al}, \mathrm{Ga})_{5} \mathrm{O}_{12}: \mathrm{Tb}^{3+}, \\
\mathrm{Y}_{2} \mathrm{Si}_{2} \mathrm{O}_{7}: \mathrm{Tb}^{3+}\end{array}$ & 227,267 & $4 \mathrm{f}^{8} \rightarrow 4 \mathrm{f}^{7} 5 \mathrm{~d}^{1}$ & $489,544,561,625$ & $\begin{array}{l}{ }^{5} \mathrm{D}_{4} \rightarrow{ }^{7} \mathrm{~F}_{6},{ }^{5} \mathrm{D}_{4} \rightarrow{ }^{7} \mathrm{~F}_{5} \\
{ }^{5} \mathrm{D}_{4} \rightarrow{ }^{7} \mathrm{~F}_{4},{ }^{5} \mathrm{D}_{4} \rightarrow{ }^{7} \mathrm{~F}_{3}\end{array}$ & [96] \\
\hline $\mathrm{Y}_{3}(\mathrm{Al}, \mathrm{Ga})_{5} \mathrm{O}_{12}: \mathrm{Tb}$ & 229,265 & $4 f^{8} \rightarrow 4 f^{7} 5 d^{1}$ & $489,544,561,625$ & $\begin{array}{l}{ }^{5} \mathrm{D}_{4} \rightarrow{ }^{7} \mathrm{~F}_{6},{ }^{5} \mathrm{D}_{4} \rightarrow{ }^{7} \mathrm{~F}_{5} \\
{ }^{5} \mathrm{D}_{4} \rightarrow{ }^{7} \mathrm{~F}_{4},{ }^{5} \mathrm{D}_{4} \rightarrow{ }^{7} \mathrm{~F}_{3}\end{array}$ & {$[96,97]$} \\
\hline $\mathrm{La}_{0.5} \mathrm{Gd}_{1.5} \mathrm{SiO}_{5}: \mathrm{Dy}^{3+}$ & 226 & $\begin{array}{c}\text { Transition from } \\
\text { oxygen } 2 \mathrm{p}(\mathrm{O} 2 \mathrm{p}) \\
\text { valence band to the } \\
\mathrm{La}(5 \mathrm{~d} 6 \mathrm{~s}) \text { and } \\
\text { Gd(5d6s) conduction } \\
\text { bands }\end{array}$ & $488,578,668,756$ & $\begin{array}{c}{ }^{4} \mathrm{~F}_{9 / 2} \rightarrow{ }^{6} \mathrm{H}_{15 / 2},{ }^{4} \mathrm{~F}_{9 / 2} \rightarrow \\
{ }^{6} \mathrm{H}_{13 / 2},{ }^{4} \mathrm{~F}_{9 / 2} \rightarrow{ }^{6} \mathrm{H}_{11 / 12} \\
{ }^{4} \mathrm{~F}_{9 / 2} \rightarrow{ }^{6} \mathrm{H}_{9 / 2}\end{array}$ & [22] \\
\hline $\mathrm{ZnO}: \mathrm{Tb}^{3+}$ & 325 & 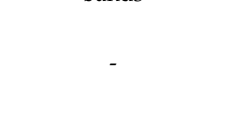 & $378,415,448,517$ & $\begin{array}{c}\text { Band to band emission } \\
\text { in } \mathrm{ZnO} \text {, zinc vacancies, } \\
\text { zinc interstitials, oxygen } \\
\text { vacancies }\end{array}$ & [64] \\
\hline $\mathrm{Y}_{3}(\mathrm{Al}, \mathrm{Ga})_{5} \mathrm{O}_{12}: \mathrm{Ce}^{3+}$ & 345,435 & ${ }^{2} \mathrm{f}_{7 / 2} \rightarrow 5 \mathrm{~d}$ & 502,545 & $5 d \rightarrow{ }^{2} f_{5 / 2}, 5 d \rightarrow{ }^{2} f_{7 / 2}$ & [72] \\
\hline CdS & - & - & 499,512 & $\begin{array}{l}\text { impurity states, defects } \\
\text { from host }\end{array}$ & [98] \\
\hline $\mathrm{Y}_{2} \mathrm{SiO}_{5}: \mathrm{Tb}^{3+}$ & 254 & - & $489,544,561$ & 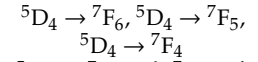 & {$[96,99]$} \\
\hline $\mathrm{CaS}: \mathrm{Eu}^{2+}$ & 220,470 & band-to-band, $\mathrm{f} \rightarrow \mathrm{d}$ & 618,650 & $\begin{array}{c}{ }^{5} \mathrm{D}_{0} \rightarrow{ }^{7} \mathrm{~F}_{2}, 4 \mathrm{f}^{6}\left[^{7} \mathrm{f}_{0}\right] 5 \mathrm{~d}^{1} \\
\left(\mathrm{t}_{2 \mathrm{~g}}\right) \stackrel{\rightarrow}{\rightarrow} 4 \mathrm{f}^{7}\left({ }^{8} \mathrm{~S}_{7 / 2}\right)\end{array}$ & [100] \\
\hline $\mathrm{CaS}: \mathrm{Eu}^{2+}$ & $250,320,470$ & $\begin{array}{c}\text { band-to-band, } \\
4 \mathrm{f}^{7}\left[{ }^{8} \mathrm{~S}_{7 / 2}\right] \rightarrow \\
4 \mathrm{f}^{6}\left[{ }^{7} \mathrm{~F}_{\mathrm{J}}\right] 5 \mathrm{~d}^{1}\left[\mathrm{e}_{\mathrm{g}}\right] \\
4 \mathrm{f}^{7}\left[{ }^{8} \mathrm{~S}_{7 / 2}\right] \rightarrow \\
4 \mathrm{f}^{6}\left[{ }^{7} \mathrm{~F}_{\mathrm{J}}\right] 5 \mathrm{~d}^{1}\left[\mathrm{t}_{2 \mathrm{~g}}\right]\end{array}$ & 650 & $\begin{array}{c}4 \mathrm{f}^{6}\left[{ }^{7} \mathrm{f}_{0}\right] 5 \mathrm{~d}^{1}\left(\mathrm{t}_{2 \mathrm{~g}}\right) \rightarrow \\
4 \mathrm{f}^{7}\left({ }^{8} \mathrm{~S}_{7 / 2}\right)\end{array}$ & [75] \\
\hline $\mathrm{Gd}_{2} \mathrm{O}_{2} \mathrm{~S}: \mathrm{Tb}^{3+}$ & 275 & - & $490,545,588,620$ & $\begin{array}{l}{ }^{5} \mathrm{D}_{4} \rightarrow{ }^{7} \mathrm{~F}_{6},{ }^{5} \mathrm{D}_{4} \rightarrow{ }^{7} \mathrm{~F}_{5} \\
{ }^{5} \mathrm{D}_{4} \rightarrow{ }^{7} \mathrm{~F}_{4},{ }^{5} \mathrm{D}_{4} \rightarrow{ }^{7} \mathrm{~F}_{3} \\
{ }^{5} \mathrm{D}_{3} \rightarrow{ }^{7} \mathrm{~F}_{6},{ }^{5} \mathrm{D}_{3} \rightarrow{ }^{7} \mathrm{~F}_{5},\end{array}$ & [101] \\
\hline $\mathrm{Y}_{3} \mathrm{Al}_{5} \mathrm{O}_{12}: \mathrm{Tb}$ & 250 & - & $\begin{array}{c}362,398,422,470 \\
545,570,610\end{array}$ & $\begin{array}{c}{ }^{5} \mathrm{D}_{3} \rightarrow{ }^{7} \mathrm{~F}_{4},{ }^{5} \mathrm{D}_{4} \rightarrow{ }^{7} \mathrm{~F}_{6} \\
{ }^{5} \mathrm{D}_{4} \rightarrow{ }^{7} \mathrm{~F}_{5},{ }^{5} \mathrm{D}_{4} \rightarrow{ }^{7} \mathrm{~F}_{4} \\
{ }^{5} \mathrm{D}_{4} \rightarrow{ }^{7} \mathrm{~F}_{3}\end{array}$ & [102] \\
\hline $\mathrm{SrAl}_{2} \mathrm{O} 4: \mathrm{Eu}^{2+}, \mathrm{Dy}^{3+}$ & 325 & - & 525 & $5 d-4 f$ & {$[103,104]$} \\
\hline $\mathrm{ZnGa}_{2} \mathrm{O}_{4}: \mathrm{Mn}$ & 290 & - & 508 & ${ }^{4} \mathrm{~T}_{1} \rightarrow{ }^{6} \mathrm{~A}_{1}$ & [105] \\
\hline $\mathrm{ZnS}: \mathrm{Mn}$ & 488 & - & 590 & ${ }^{4} \mathrm{~T}_{1}(\mathrm{G}) \rightarrow{ }^{6} \mathrm{~A}_{1}(\mathrm{~S})$ & [106] \\
\hline
\end{tabular}




\section{Other Potential Applications of PLD}

Biomaterials are widely used for replacing irreversibly damaged tissues in the human body, which demand good functioning and long-term durability of the implants, namely biocompatibility, good corrosion and fatigue resistance, wear resistance and biomechanical compatibility [107]. In vivo studies of polarized hydroxyapatite ceramics have shown polarized samples to induce improvements in bone ingrowths. Many piezoelectric ceramics proposed for implants are based on perovskite oxide ferroelectric barium titanate $\mathrm{BaTiO}_{3}$ (BTO) Jelinek et al. [108] has successfully deposited BTiO layers by $\mathrm{PLD}$ on $\mathrm{TiNb}, \mathrm{Pt} / \mathrm{TiNb}, \mathrm{Si}(100)$ and fused silica substrates using various deposition conditions.

Si wafers are extremely utilized substrates to build electronic devices, such as complementary metal-oxide-semiconductor chips and BTO is an important perovskite ferroelectric oxide due to its high-dielectric constant and large piezoelectric coefficient. BTO thin films have been studied for many applications such as piezoelectric detectors, thin film capacitors and magnetoelectric devices. The deposition of BTO thin films with PLD on the Si substrates, paved the way to integrate BTO into microelectronic devices [109].

PLD films have also been applied as protective barriers in corrosive environments. Amorphous Ta-Ni films produced by PLD offer extremely high corrosion resistance in both acid and alkaline solutions. An $\mathrm{Y}_{2} \mathrm{O}_{3}$ thin film $(160 \mathrm{~nm})$ deposited on the $\mathrm{Zn}-22 \mathrm{Al}-2 \mathrm{Cu}$ alloy produced an improvement of up to $75 \%$ in corrosion resistance in aerated water of $\mathrm{pH} 4.5$, in comparison with the alloy without the film. In addition, the PLD technique can be used to form alumina-stabilized zirconia films on fused silica substrates for both corrosion resistance and thermal barrier purposes [110].

A femtosecond PLD has been used by Murry et al. [111] to fabricate solid state nanoparticulate Si thin films on a fused silica substrate. Fabrication parameters have been studied in order to form high quality thin films with a continuous film profile and a smooth surface, ideal for optical and optoelectronic applications.

\section{Conclusions and Challenges}

Luminescence materials otherwise known as phosphors have found applications in electronic information display, advertising, solid-state lighting, solar cells, theft prevention, medicine, data storage, quality control, optical amplifiers, optical laser, scintillation and temperature measurement in both industrial and biological systems. Although phosphors comes in a powder form, most of their applications is based on thin film forms. In most commercial applications, for example in optical industries, microelectronics and other modern technologies, films of uniform thickness on large-area substrates are of interest. PLD is widely used in the research laboratories for the growth of thin luminescent films because of the simplicity of the technique. Furthermore, it is quite promising for diverse commercial applications, particularly, in the growth of large-area thin films. This review was a brief overview of application of the PLD technique in the preparation of luminescence materials. Compared to other popular techniques such as vapor deposition and chemical vapor deposition (CVD), PLD offers flexibility in terms of deposition parameters such as background gas, laser parameters, deposition time and substrate to target distance, which can be varied to enhance the quality and optimize the fundamental properties of the films. Major advantages of the PLD are its ability to transfer the stoichiometry of the target material to the substrate, high temperature deposition and high rate of deposition. Since there are needs to make most devices smaller, it is crucial to develop a technique that can deposit a nanoscale layer thin films. PLD has been used to deposit thin films of thickness as low as $5 \mathrm{~nm}$. Several devices such as photovoltaic cells, electrostimulators, photodetectors and LEDs have been fabricated using the PLD technique. One of the major drawbacks of the PLD is splashing. The splashing phenomenon can be reduced or eliminated by smoothening the surface of the target after each deposition. Smooth surface help in reducing splashing since it minimizes the presence of rough irregularities, which cause defoliation by the laser beam. Another way of reducing splashing is by making the target as dense as possible. A dense target reduces or avoids the exfoliation of the material from the target surface during laser impact. Splashing can also be reduced by using low laser 
power density. The energy density of the laser should be slightly above the evaporation threshold of the material. Furthermore, different deposition arrangements that have been developed recently to minimize or eliminates splashing during film deposition were discussed in Section 3.

Author Contributions: S.N.O., Conceptualization; S.N.O., Formal Analysis; S.N.O., Investigation; S.N.O., Methodology; S.N.O., Wrote original draft; O.M.N., Review and Editing of the Paper; H.C.S., Project owner; H.C.S., Conceptualization; H.C.S., Funding acquisition; H.C.S., Methodology; H.C.S., Project administration; H.C.S., Resources; H.C.S., Supervision; H.C.S., Review and Editing of the Paper. All authors have read and agreed to the published version of the manuscript.

Funding: This research was funded by the South African Research Chairs Initiative of the Department of Science and Technology and the National Research Foundation of South Africa grant number 84415 and the University of the Free State, South Africa.

Acknowledgments: The authors express their sincere thanks to the South African Research Chairs Initiative of the Department of Science and Technology and the National Research Foundation of South Africa (84415). The financial assistance from the University of the Free State, South Africa is highly recognized. The National Laser centre and African Laser centre are acknowledged for the supply of the lasers used in the study.

Conflicts of Interest: The authors declare that they have no known competing financial interests or personal relationships that could have appeared to influence the work reported in this paper.

\section{References}

1. Smith, H.M.; Turner, A.F. Vacuum deposited thin films using a ruby laser. Appl. Opt. 1965, 4, 147-148. [CrossRef]

2. Dijkkamp, D.; Venkatesan, T.; Wu, X.D.; Shareen, S.A.; Jiswari, N.; Min-Lee, Y.H.; McLean, W.L.; Croft, M. Preparation of Y-Ba-Cu oxide superconductor thin films using pulsed laser evaporation from high $\mathrm{T}_{\mathrm{C}}$ bulk material. Appl. Phys. Lett. 1987, 51, 619-621. [CrossRef]

3. Venkayesan, T. (Ed.) Symposium I: Recent Advances in the Pulsed Laser Deposition of Thin Films and Nanostructures, MRS Singapore ICMAT Symposia Proceedings, Procedia Engineering; Elsevier: Amsterdam, The Netherlands, 2013.

4. Norton, D.P. Pulsed laser deposition of complex materials: Progress towards applications. In Pulsed laser Deposition of Thin FILMS: Applications-Led Growth of Functional Materials; Eason, R., Ed.; John Wiley \& Sons Inc.: Hoboken, NJ, USA, 2007; pp. 3-5.

5. Krebs, H.; Weisheit, M.; Faupel, J.; Süske, E.; Scharf, T.; Fuhse, C.; Störmer, M.; Sturm, K.; Seibt, M.; Kijewski, H.; et al. Pulsed laser deposition (PLD)—A versatile thin film technique. In Advances in Solid State Physics; Kramer, B., Ed.; Springer: Berlin/Heidelberg, Germany, 2003; Volume 43, pp. 505-518. [CrossRef]

6. Bleu, Y.; Bourquard, F.; Tite, T.; Loir, A.; Maddi, C.; Donnet, C.; Garrelie, F. Review of graphene growth from a solid carbon source by pulsed laser deposition (PLD). Front. Chem. 2018, 6, 572. [CrossRef] [PubMed]

7. Coetsee, E.; Terblans, J.J.; Swart, H.C. Characteristic properties of $\mathrm{Y}_{2} \mathrm{SiO}_{5}$ : Ce thin films grown with PLD. Phys. B Phys. Condens. Matter 2009, 404, 4431-4435. [CrossRef]

8. Yousif, A.; Duvenhage, M.M.; Terblans, J.J.; Ntwaeaborwa, O.M.; Swart, H.C. Role of target and Ga particulates on the surface and optical properties of $\mathrm{Y}_{3}(\mathrm{Al}, \mathrm{Ga})_{5} \mathrm{O}_{12}$ : Tb thin films prepared by PLD. Phys. B Phys. Condens. Matter 2018, 535, 319-322. [CrossRef]

9. Gamaly, E.G.; Rode, A.V.; Davies, B.L. Ultrafast laser ablation and film deposition. In Pulsed Laser Deposition of Thin Films-Applications-Led Growth of Functional Materials; Eason, R., Ed.; John Wiley \& Sons, Inc.: Hoboken, NJ, USA, 2007; pp. 99-129.

10. Steen, W.M. Laser Material Processing; Springer-Verlag: London, UK, 1991; pp. 81-89. [CrossRef]

11. Bäuerle, D. Laser Processing and Chemistry, 3rd ed.; Springer: Berlin/Heidelberg, Germany, 2000; p. 221.

12. Bäuerle, D. Laser Processing and Chemistry, 4th ed.; Springer: Berlin/Heidelberg, Germany, 2011; p. 20.

13. Bäuerle, D. Laser Processing and Chemistry, 3rd ed.; Springer: Berlin/Heidelberg, Germany, 2000; p. 226.

14. Schou, J. Laser beam-solid Interactions: Fundamental aspects. In Materials Surface Processing by Directed Energy Techniques, 1st ed.; Pauleau, Y., Ed.; E-MRS: Great Britain, UK, 2006; pp. 35-66.

15. Michail, C.M.; Toutountzis, A.; Valais, I.G.; Seferis, I.; Georgousis, M.; Fountos, G.; Kandarakis, I.S.; Panayiotakis, G.S. Luminescence efficiency of $\mathrm{Gd}_{2} \mathrm{O}_{2} \mathrm{~S}$ : Eu powder phosphor as x-ray to light convertor. Sci. Technol. 2010, 2, 25-32.

16. Soltan, S. Interaction of Superconductivity and Ferromagnetism in YBCO-LCMO Heterostructures; Cuvillier Verlag: Göttingen, Germany, 2005; p. 63. 
17. Nishinaga, T.; Scheel, H.J. Crystal growth aspects of high-Tc superconductors, In Advances in Superconductivity VIII; Hayakawa, H., Enomoto, Y., Eds.; Springer: Tokyo, Japan, 1996; pp. 33-38. [CrossRef]

18. Le, P.H.; Luo, C.W. Thermoelectric and topological insulator bismuth chalcogenide thin films grown using pulsed laser deposition. In Applications of Laser Ablation-Thin Film Deposition, Nanomaterial Synthesis and Surface Modification; Yang, D., Ed.; InTech: Rijeka, Croatia, 2016; pp. 55-84.

19. Richardson, J.J.; Lange, F.F. Low Temperature Continuous Circulation Reactor for the Aqueous Synthesis of ZnO Films, Nanostructures, and Bulk Single Crystals. US patent No: US 8926750 B2, 2015.

20. Metev, S.; Meteva, K. Nucleation and growth of laser-plasma deposited thin films. Appl. Surf. Sci. 1989, 43, 402-408. [CrossRef]

21. Schneider, C.W.; Lippert, T. Laser ablation and thin film deposition. In Laser Processing of Materials; Schaaf, P., Ed.; Springer Series in Materials Science; Springer: Berlin/Heidelberg, Germany, 2010; Volume 139, pp. 89-112. [CrossRef]

22. Ogugua, S.N.; Nyenge, R.L.; Sechogela, P.T.; Swart, H.C.; Ntwaeaborwa, O.M. Influence of deposition atmosphere and substrate temperature on the structure, morphology, and photoluminescence of pulsed laser deposited $\mathrm{La}_{0.5} \mathrm{Gd}_{1.5} \mathrm{SiO}_{5}: \mathrm{Dy}^{3+}$. J. Vac. Sci. Technol. A 2016, 34, 021520-12. [CrossRef]

23. Cheung, J.T. History and fundamentals of pulsed laser deposition. In Pulsed Laser Deposition of Thin Films, 1st ed.; Chrisey, D.B., Hubler, G.K., Eds.; Wiley Interscience: New York, NY, USA, 1994; pp. 1-19.

24. Kumar, A.; Ganapathi, L.; Kanetkar, S.M.; Narayan, J. Single-chamber, in situ processing of superconducting $\mathrm{YBa}_{2} \mathrm{Cu}_{3} \mathrm{O}_{7-\delta}$ thin films on stainless steel with yttria-stabilized zirconia buffer layer. J. Appl. Phys. 1991, 69, 2410-2413. [CrossRef]

25. Wu, K.H.; Chen, S.P.; Juang, J.Y.; Uen, T.M.; Gou, Y.S. Investigation of the evolution of $\mathrm{YBa}_{2} \mathrm{Cu}_{3} \mathrm{O}_{7-\delta}$ films deposited by scanning pulsed laser deposition on different substrates. Physica C 1997, 289, 230-242. [CrossRef]

26. Yap, S.S.; Tou, T.Y. Diamond-like carbon formation for various positions by pulsed laser deposition. Appl. Surf. Sci. 2005, 248, 340-343. [CrossRef]

27. McGill, R.A.; Chrisey, D.B. Method of Producing a Film Coating by Matrix Assisted Pulsed Laser Deposition. US patent No: US 006025036A, 15 February 2000.

28. Greer, J.A.; Howard, B.; Paradise, M.; Ivnitskiy, S.N.; Lations, D. Target Manipulation for Pulsed Laser Deposition. US patent No: US0067389A1, 2005.

29. Fischer, D.; de la Fuente, G.F.; Jansen, M. A new pulsed laser deposition technique: Scanning multi-component pulsed laser deposition method. Rev. Sci. Instrum. 2012, 83, 043901-043908. [CrossRef] [PubMed]

30. Benetti, D.; Nouar, R.; Nechache, R.; Pepin, H.; Sarkissian, A.; Rosei, F.; MacLeod, J.M. Combined magnetron sputtering and pulsed laser deposition of $\mathrm{TiO}_{2}$ and BFCO thin films. Sci. Rep. 2017, 7, 2503-2511. [CrossRef]

31. Caricato, A.P.; Capone, S.; Epifani, M.; Lomascolo, M.; Luches, A.; Martino, M.; Romano, F.; Rella, R.; Siciliano, P.; Spadavecchia, J.; et al. Nanoparticle thin films deposited by MAPLE for sensor applications. In Fundamentals of Laser Assisted Micro- and Nanotechnologies; Veiko, V.P., Konov, V.I., Eds.; Springer: Cham, Switzerland; Heidelberg, Germany; New York, NY, USA, 2008; Volume 195.

32. Piqué, A.; McGill, R.A.; Chrisey, D.B.; Leonhardt, D.; Mslna, T.E.; Spargo, B.J.; Callahan, J.H.; Vachet, R.W.; Chung, R.; Bucaro, M.A. Growth of organic thin films by the matrix assisted pulsed laser evaporation (MAPLE) technique. Thin Solid Films 1999, 355-356, 536-541. [CrossRef]

33. Piqué, A. The Matrix-Assisted Pulsed Laser Evaporation (MAPLE) process: Origins and future directions. Appl. Phys. A 2011, 105, 517-528. [CrossRef]

34. McGill, R.A.; Chrisey, R.B.; Pique, A.; Mlsna, T.E. Matrix-assisted pulsed-laser evaporation (MAPLE) of functionalized polymers: Applications with chemical sensors. In Laser Applications in Microelectronic and Optoelectronic Manufacturing III; Dubowski, J.J., Dyer, P.E., Eds.; Proc. SPIE: San Jose, CA, USA, 1999; Volume 3618, pp. 255-266, ISBN 0-8194-3088-9.

35. Piqué, A.; Chrisey, D.B.; Spargo, B.J.; Bucaro, M.A.; Vachet, R.W.; Mlsna, T.; Leonhardt, D.; Mcgill, R.A.; Callahan, J.H.; Chung, R. Use of Matrix Assisted Pulsed Laser Evaporation (Maple) for the growth of organic thin films. MRS Proc. 1998, 526, 421-426. [CrossRef]

36. Bloisi, F.; Cassinese, A.; Papa, R.; Vicari, L.; Califano, V. Matrix-Assisted Pulsed Laser Evaporation of polythiophene films. Thin Solid Films 2008, 516, 1594-1598. [CrossRef] 
37. Sima, F.; Davidson, P.; Pauthe, E.; Sima, L.E.; Gallet, O.; Mihailescu, I.N.; Anselme, K. Fibronectin layers by matrix-assisted pulsed laser evaporation from saline buffer-based cryogenic targets. Acta Biomater. 2011, 7, 3780-3788. [CrossRef] [PubMed]

38. Caricato, A.P.; Luches, A. Applications of the matrix-assisted pulsed laser evaporation method for the deposition of organic, biological and nanoparticle thin films: A review. Appl. Phys. A 2011, 105, 565-582. [CrossRef]

39. Yang, S.; Zhang, J. Matrix-Assisted Pulsed Laser Evaporation (MAPLE) technique for deposition of hybrid nanostructures. Front. Nanosci. Nanotechnol. 2017, 3, 1-9. [CrossRef]

40. Kompitsas, M.; Giannoudakos, A.; György, E.; Sauthier, G.; Figueras, A.; Mihailescu, I.N. Growth of metal-oxide semiconductor nanocomposite thin films by a dual-laser, dual target deposition system. Thin Solid Films 2007, 515, 8582-8585. [CrossRef]

41. György, E.; Sauthier, G.; Figueras, A.; Giannoudakos, A.; Kompitsas, M.; Mihailescu, I.N. Growth of Au-TiO 2 nanocomposite thin films by a dual-laser, dual-target system. J. Appl. Phys. 2006, 100, 114302-114306. [CrossRef]

42. Eason, R.W.; May-Smith, T.C.; Sloyan, K.A.; Gazia, R.; Darby, M.S.B.; Sposito, A.; Parsonage, T.L. Multi-beam pulsed laser deposition for advanced thin-film optical waveguides. J. Phys. D Appl. Phys. 2014, 47, 034007-034021. [CrossRef]

43. Eason, R.W.; May-Smith, T.C.; Grivas, C.; Darby, M.S.B.; Shepherd, D.P.; Gazia, R. Current state-of-the-art of pulsed laser deposition of optical waveguide structures: Existing capabilities and future trends. Appl. Surf. Sci. 2009, 255, 5199-5205. [CrossRef]

44. Veenas, C.L.; Nissamudeen, K.M.; Smitha, S.L.; Biju, V.; Gopchandran, K.G. Off-axis PLD: A novel technique for plasmonic engineering of silver nanoparticles. J. Optoelectron. Adv. M 2009, 11, 114-122.

45. Hinton, M.J.; Yong, J.; Steers, S.; Lemberger, T.R. Comparison of 2-D quantum and thermal critical fluctuations of underdoped $\mathrm{Bi}_{2} \mathrm{Sr}_{2} \mathrm{CaCu}_{2} \mathrm{O}_{8+\delta}$ with ultrathin $\mathrm{YBa}_{2} \mathrm{Cu}_{3} \mathrm{O}_{7-\delta}$. J. Supercond. Nov. Magn. 2013, 26, 2617-2620. [CrossRef]

46. Siegert, M.; Zander, W.; Lisoni, J.; Schubert, J.; Buchal, C. Off-axis pulsed laser deposition system for epitaxial oxide growth on substrates up to 2 inches in diameter. Appl. Phys. A 1999, 69, S779-S781. [CrossRef]

47. Elhmaidi, Z.O.; Abd-Lefdil, M.; El Khakani, M.A. Photoconversion Optimization of pulsed-laser-deposited p-CZTS/n-Si-nanowires heterojunction-based photovoltaic devices. Nanomaterials 2020, 10, 1393-13106. [CrossRef]

48. Kadhim, A.; Harrison, P.; Meeth, J.; Al-Mebir, A.; Zeng, G.; Wu, J. Development of combinatorial pulsed laser deposition for expedited device optimization in CdTe/CdS thin-film solar cells. Int. J. Opt. 2016, 2016, 1-7. [CrossRef]

49. Beloso, A.L.A.; Varela, M.D.B.; Rodríguez, A.F.; O'connor, G.; Trigo, E.P.; Álvarez, A.P.; García, D.N. Fabrication of a cell electrostimulator using pulse laser deposition and laser selective thin film removal. In Laser Ablation: From Fundamentals to Applications; Itina, T.E., Ed.; INTECH: Rijeka, Croatia, 2017; pp. 227-242. [CrossRef]

50. Wang, B.; Zhang, Z.B.; Zhong, S.P.; Zheng, Z.Q.; Xu, P.; Zhang, H. Recent progress in high-performance photo-detectors enabled by the pulsed laser deposition technology. J. Mater. Chem. C 2020, 8, 4988-5014. [CrossRef]

51. Sarkar, A.; Katiyar, A.K.; Mukherjee, S.; Singh, S.; Singh, S.K.; Das, A.K.; Ray, S.K. Geometry controlled white light emission and extraction in CdS/Black-Si conical heterojunctions. ACS Appl. Electron. Mater. 2019, 1, 25-33. [CrossRef]

52. Kim, H.S.; Lugo, F.; Pearton, S.J.; Norton, D.P.; Wang, Y.L.; Ren, F. Phosphorus doped ZnO light emitting diodes fabricated via pulsed laser deposition. Appl. Phys. Lett. 2008, 92, 112108-112110. [CrossRef]

53. Bayram, C.; Teherani, F.H.; Rogers, D.J.; Razeghi, M. Hybrid green LEDs based on n-ZnO/(InGaN/GaN) multi-quantum-wells/p-GaN. Proc. SPIE 2009, 7217, 72170P-7. [CrossRef]

54. Cheng, X.; Xu, S.W.; Lu, Y.M.; Han, S.; Cao, P.J.; Jia, F.; Zeng, Y.X.; Liu, X.K.; Xu, W.Y.; Liu, W.J.; et al. Fabrication of tunable $\mathrm{n}-\mathrm{Zn}_{1-\mathrm{x}} \mathrm{Cd}_{\mathrm{x}} \mathrm{O} / \mathrm{p}-\mathrm{GaN}$ heterojunction light-emitting diodes. J. Alloys Compd. 2019, 776, 646-653. [CrossRef]

55. Su, S.; Ling, C.; Azad, F.; Zeng, H.; Lu, Y.; Xing, S. Fabrication and modification of $n-\mathrm{ZnO} / p-\mathrm{GaN}$ heterojunction light emitting diodes with white light emission characteristics. Nanosci. Nanotechnol. 2017, 9, 880-884. [CrossRef] 
56. Huang, Y.; Zhou, X.; Zhang, L.; Lin, G.; Xu, M.; Zhao, Y.; Jiao, M.; Zhang, D.; Pan, B.; Zhu, L.; et al. Tunable electroluminescence from an $\mathrm{n}-\mathrm{ZnO} / \mathrm{p}-\mathrm{GaN}$ heterojunction with a $\mathrm{CsPbBr}_{3}$ interlayer grown by pulsed laser deposition. J. Mater. Chem. C 2020, 8, 12240-12246. [CrossRef]

57. Zhang, L.; Li, Q.; Wang, F.; Qu, C.; Zhao, F. Room temperature electroluminescence from n-ZnO:Ga/i-ZnO/p-GaN:Mg heterojunction device grown by PLD. Electron. Mater. Lett. 2014, 10, 661-664. [CrossRef]

58. Singh, J.; Srivastava, P.K.; Siwach, P.K.; Singh, H.K.; Tiwari, R.S.; Srivastava, O.N. PLD deposited ZnO films on different substrates and oxygen pressure: A study of surface morphology and optical properties. Sci. Adv. Mater. 2012, 4, 467-474. [CrossRef]

59. Goyal, A.; Yadav, B.S.; Thakur, O.P.; Kapoor, A.K.; Muralidharan, R. Effect of annealing on $\beta-\mathrm{Ga}_{2} \mathrm{O}_{3}$ film grown by pulsed laser deposition technique. J. Alloys Compd. 2014, 583, 214-219. [CrossRef]

60. Schilling, M.; Guillaume, A.; Scholtyssek, J.M.; Ludwig, F. Design of experiments for highly reproducible pulsed laser deposition of $\mathrm{YBa}_{2} \mathrm{Cu}_{3} \mathrm{O}_{7}-\delta$. J. Phys. D. Appl. Phys. 2014, 47, 034008-034017. [CrossRef]

61. Wakabayashi, R.; Oshima, T.; Hattori, M.; Sasaki, K.; Masui, T.; Kuramata, A.; Yamakoshi, S.; Yoshimatsu, K.; Ohtomo, A. Oxygen-radical-assisted pulsed-laser deposition of $\beta-\mathrm{Ga}_{2} \mathrm{O}_{3}$ and $\beta-\left(\mathrm{Al}_{\mathrm{x}} \mathrm{Ga}_{1-\mathrm{x}}\right)_{2} \mathrm{O}_{3}$ films. J. Cryst. Growth 2015, 424, 77-79. [CrossRef]

62. Mandal, S.K.; Roy, R.K.; Pal, A.K. Effect of particle shape distribution on the surface plasmon resonance of Ag- $\mathrm{SiO}_{2}$ nanocomposite thin films. J. Phys. D Appl. Phys. 2003, 36, 261-265. [CrossRef]

63. Ogugua, S.N.; Swart, H.C.; Ntwaeaborwa, O.M. Effects of deposition environment and temperature on photoluminescence, morphology, and crystal structure of pulsed laser deposited $\mathrm{Ga}_{2} \mathrm{O}_{3}$ thin films. J. Vac. Sci. Technol. A 2020, 38, 043407-043418. [CrossRef]

64. Kumar, V.; Ntwaeaborwa, O.M.; Coetsee, E.; Swart, H.C. Role of deposition time on the properties of ZnO: $\mathrm{Tb}^{3+}$ thin films prepared by pulsed laser deposition. J. Colloid Interface Sci. 2016, 474, 129-136. [CrossRef]

65. Shukla, G. ZnO/MgZnO p-n junction light-emitting diodes fabricated on sapphire substrates by pulsed laser deposition technique. J. Phys. D Appl. Phys. 2009, 42, 075105-075111. [CrossRef]

66. Sulaiman, N.S.C.; Nee, C.H.; Yap, S.L.; Lee, Y.S.; Tou, T.Y.; Yap, S.S. The growth of nanostructured $\mathrm{Cu}_{2} \mathrm{ZnSnS}_{4}$ films by pulsed laser deposition. Appl. Surf. Sci. 2015, 354, 42-47. [CrossRef]

67. Kim, H.; Horwitz, J.S.; Kafafi, Z.H.; Pique, A.; Kushto, G.P. Pulsed Laser Deposition of Transparent Conducting Thin Films on Flexible Substrates. US Patent No: US0068 18924B2, 11 November 2003.

68. Allabergenov, B.; Chung, S.; Jeong, S.M.; Kim, S.; Choi, B. Enhanced blue photoluminescence realized by copper diffusion doping of $\mathrm{ZnO}$ thin films. Opt. Mater. Express 2013, 3, 1733-1741. [CrossRef]

69. Hasabeldaim, E.; Ntwaeaborwa, O.M.; Kroon, R.E.; Coetsee, E.; Swart, H.C. Effect of substrate temperature and post annealing temperature on ZnO:Zn PLD thin film properties. Opt. Mater. 2017, 74, 139-149. [CrossRef]

70. Hasabeldaim, E.; Ntwaeaborwa, O.M.; Kroon, R.E.; Motaung, D.E.; Coetsee, E.; Swart, H.C. Effect of PLD growth atmosphere on the physical properties of $\mathrm{ZnO}$ : Zn thin films. Opt. Mater. 2017, 74, 76-85. [CrossRef]

71. Zheng, Z.Q.; Yao, J.D.; Yang, G.W. Growth of centimeter-scale high-quality $\mathrm{In}_{2} \mathrm{Se}_{3}$ films for transparent, flexible and high performance photodetectors. J. Mater. Chem. C 2016, 4, 8094-8103. [CrossRef]

72. Dlamini, S.T.S.; Swart, H.C.; Terblans, J.J.; Ntwaeaborwa, O.M. The effect of different gas atmospheres on the structure, morphology and photoluminescence properties of pulsed laser deposited $\mathrm{Y}_{3}(\mathrm{Al}, \mathrm{Ga}) 5 \mathrm{O}_{12}: \mathrm{Ce}^{3+}$ nano thin films. Solid State Sci. 2013, 23, 65-71. [CrossRef]

73. Splith, D.; Müller, S.; Schmidt, F.; von Wenckstern, H.; van Rensburg, J.J.; Meyer, W.E.; Grundmann, M. Determination of the mean and the homogeneous barrier height of $\mathrm{Cu}$ Schottky contacts on heteroepitaxial $\beta-\mathrm{Ga}_{2} \mathrm{O}_{3}$ thin films grown by pulsed laser deposition. Phys. Status Solidi A 2014, 211, 40-47. [CrossRef]

74. Cai, Y.; Zhang, K.; Feng, Q.; Zuo, Y.; Hu, Z.; Feng, Z.; Zhou, H.; Lu, X.; Zhang, C.; Tang, W.; et al. Tin-assisted growth of $\varepsilon-\mathrm{Ga}_{2} \mathrm{O}_{3}$ film and the fabrication of photodetectors on sapphire substrate by PLD. Opt. Mater. Express 2018, 8, 3506-3517. [CrossRef]

75. Nyenge, R.L.; Sechogela, P.T.; Swart, H.C.; Ntwaeaborwa, O.M. The influence of laser wavelength on the structure, morphology, and photoluminescence properties of pulsed laser deposited CaS: $\mathrm{Eu}^{2+}$ thin films. J. Mod. Opt. 2015, 62, 1102-1109. [CrossRef]

76. Kato, K.; Dang, F.; Mimura, K.; Kinemuchi, Y.; Imai, H.; Wada, S.; Osada, M.; Haneda, H.; Kuwabara, M. Nano-sized cube-shaped single crystalline oxides and their potentials; composition, assembly and functions. Adv. Powder Technol. 2014, 25, 1401-1414. [CrossRef] 
77. Zhang, R.; Liu, X.; Shi, L.; Jin, X.; Dong, Y.; Li, K.; Zhao, X.; Li, Q.; Deng, Y. A Simple and Fast Method to Synthesize Cubic Iridium Nanoparticles with Clean Surface Free from Surfactants. Nanomaterials 2019, 9, 76. [CrossRef] [PubMed]

78. Canham, L.T. Silicon quantum wire array fabrication by electrochemical and chemical dissolution of wafers. Appl. Phys. Lett. 1990, 57, 1046-1048. [CrossRef]

79. Canham, L.T.; Leong, W.Y.; Beale, M.I.J.; Cox, T.I.; Taylor, L. Efficient visible electroluminescence from highly porous silicon under cathodic bias. Appl. Phys. Lett. 1992, 61, 2563-2565. [CrossRef]

80. Katiyar, A.K.; Sinha, A.K.; Manna, S.; Ray, S.K. Fabrication of Si/ZnS radial nanowire heterojunction arrays for white light emitting devices on Si substrates. ACS Appl. Mater. Interfaces 2014, 6, 15007-15014. [CrossRef]

81. Manna, S.; Das, S.; Mondal, S.P.; Singha, R.; Ray, S.K. High efficiency Si/CdS radial nanowire heterojunction photodetectors using etched Si nanowire templates. J. Phys. Chem. C 2012, 116, 7126-7133. [CrossRef]

82. Sanz, M.; Walczak, M.; de Nalda, R.; Oujja, M.; Marco, J.F.; Rodriguez, J.; Izquierdo, J.G.; Bañares, L.; Castillejo, M. Femtosecond pulsed laser deposition of nanostructured $\mathrm{TiO}_{2}$ films. Appl. Surf. Sci. 2009, 255, 5206-5210. [CrossRef]

83. Ullrich, B.; Sakai, H.; Segawa, Y. Optoelectronic properties of thin film CdS formed by ultraviolet and infrared pulsed-laser deposition. Thin Solid Films 2001, 385, 220-224. [CrossRef]

84. Aguilar-Hernandez, J.; Contreras-Puente, G.; Morales-Acevedo, A.; Vigil-Galan, O.; Cruz-Gandarilla, F.; Vidal-Larramendi, J.; Escamilla-Esquivel, A.; Hernandez-Contreras, H.; Hesiquio-Garduno, M.; Arias-Carbajal, A.; et al. Photoluminescence and structural properties of cadmium sulphide thin films grown by different techniques. Semicond. Sci. Technol. 2003, 18, 111-114. [CrossRef]

85. Abken, A.E.; Halliday, D.P.; Durose, K. Photoluminescence study of polycrystalline photovoltaic CdS thin film layers grown by close-spaced sublimation and chemical bath deposition. J. Appl. Phys. 2009, 105, 064515-9. [CrossRef]

86. Kumar, S.; Singh, R. Nanofunctional gallium oxide $\left(\mathrm{Ga}_{2} \mathrm{O}_{3}\right)$ nanowires/nanostructures and their applications in nanodevices. Phys. Status Solidi RRL 2013, 7, 781-792. [CrossRef]

87. Harwig, T.; Kellendonk, F. Some observations on the photoluminescence of doped $\beta$-galliumsesquioxide. J. Solid State Chem. 1978, 24, 255-263. [CrossRef]

88. Binet, L.; Gourier, D. Origin of the blue luminescence of $\beta-\mathrm{Ga}_{2} \mathrm{O}_{3}$. J. Phys. Chem. Solids 1998, 59, $1241-1249$. [CrossRef]

89. Tetsuyama, N.; Ishida, Y.; Higashihata, M.; Nakamura, D.; Okada, T. Fabrication of UV-LED using ZnO nanowires directly grown on $\mathrm{p}-\mathrm{GaN}$ film by NAPLD. In Proceedings of the IEEE Conference on Lasers and Electro-Optics Pacific Rim (CLEO-PR), Kyoto, Japan, 30 June-4 July 2013; pp. 1-2. [CrossRef]

90. Novoa-De León, I.C.; Johny, J.; Vázquez-Rodríguez, S.; García-Gómez, N.; Carranza-Bernal, S.; Mendivil, I.; Shaji, S.; Sepúlveda-Guzmán, S. Tuning the luminescence of nitrogen-doped graphene quantum dots synthesized by pulsed laser ablation in liquid and their use as a selective photoluminescence on-off-on probe for ascorbic acid detection. Carbon 2019, 150, 455-464. [CrossRef]

91. Caballero-Briones, F.; Santana, G.; Flores, T.; Ponce, L. Photoluminescence response in carbon films deposited by pulsed laser deposition onto GaAs substrates at low vacuum. J. Nanotechnol. 2016, 2016, 1-6. [CrossRef]

92. Yamada, Y.; Makino, T.; Suzuki, N.; Yoshida, T. Silicon nanocrystallite light emitting devices fabricated by full pulsed-laser-ablation process. Mat. Res. Soc. Symp. Proc. 2001, 638, F18-2. [CrossRef]

93. Johnson, S.L.; Bowie, C.T.; Ivanov, B.; Park, H.K.; Haglund Jr, R.F. Fabrication of polymer LEDs by resonant infrared pulsed laser ablation. Proc. SPIE 2007, 6486, 64860G-9. [CrossRef]

94. Hasabeldaim, E.; Ntwaeaborwa, O.M.; Kroon, R.E.; Swart, H.C. Surface analysis and cathodoluminescence degradation of undoped ZnO and ZnO:Zn phosphors. J. Vac. Sci. Technol. B 2016, 34, 041221-8. [CrossRef]

95. Shukla, G.; Khare, A. Effect of annealing on structural and optical properties of pulsed laser deposited titanium dioxide thin films. Adv. Mater. Res. 2009, 67, 65-70. [CrossRef]

96. Yousif, A.; Swart, H.C.; Ntwaeaborwa, O.M.; Coetsee, E. Conversion of $\mathrm{Y}_{3}(\mathrm{Al}, \mathrm{Ga})_{5} \mathrm{O}_{12}: \mathrm{Tb}^{3+}$ to $\mathrm{Y}_{2} \mathrm{Si}_{2} \mathrm{O}_{7}: \mathrm{Tb}^{3+}$ thin film by annealing at higher temperatures. Appl. Surf. Sci. 2013, 270, 331-339. [CrossRef]

97. Yousif, A.; Swart, H.C.; Ntwaeaborwa, O.M. Improved luminescence properties of pulsed laser deposited $\mathrm{Y}_{3}(\mathrm{Al}, \mathrm{Ga})_{5} \mathrm{O}_{12}: \mathrm{Tb}$ thin films by post deposition annealing. J. Lumin. 2013, 143, 201-206. [CrossRef]

98. Shen, W.P.; Kwok, H.S. Crystalline phases of II-VI compound semiconductors grown by pulsed laser deposition. Appl. Phys. Lett. 1994, 65, 2162-2164. [CrossRef] 
99. Sohn, K.; Park, D.H.; Yoo, J.G.; Kim, J.S. Luminescence of pulsed laser deposited $\mathrm{Y}_{2} \mathrm{SiO}_{5}: \mathrm{Tb}^{3+} \mathrm{thin}$ film phosphors on flat and corrugated quartz glass substrates. JPN J. Appl. Phys. 2005, 44, 1787-1791. [CrossRef]

100. Nyenge, R.L.; Shaat, S.K.K.; Noto, L.L.; Mokoena, P.P.; Swart, H.C.; Ntwaeaborwa, O.M. TOF SIMS analysis, structure and photoluminescence properties of pulsed laser deposited CaS:Eu ${ }^{2+}$ thin films. J. Lumin. 2015, 167, 172-178. [CrossRef]

101. Dolo, J.J.; Swart, H.C.; Coetsee, E.; Terblans, J.J.; Ntwaeaborwa, O.M.; Dejene, B.F. XPS analysis and luminescence properties of thin films deposited by the pulsed laser deposition technique. Hyperfine Interact. 2010, 197, 129-134. [CrossRef]

102. Hirata, G.A.; Lopez, O.A.; Shea, L.E.; Yi, J.Y.; Cheeks, T.; McKittrick, J.; Siqueiros, J.; Avalos-Borja, M.; Esparza, A.; Falcony, C. Pulsed laser deposition of $\mathrm{Y}_{3} \mathrm{Al}_{5} \mathrm{O}_{12}: \mathrm{Tb}$ photoluminescent thin films. J. Vac. Sci. Technol. A 1996, 14, 1694-1696. [CrossRef]

103. Ntwaeaborwa, O.M.; Nsimama, P.D.; Abiade, J.T.; Coetsee, E.; Swart, H.C. The effects of substrate temperature on the structure, morphology and photoluminescence properties of pulsed laser deposited $\mathrm{SrAl}_{2} \mathrm{O}_{4}: \mathrm{Eu}^{2+}$, $\mathrm{Dy}^{3+}$ thin films. Physica B 2009, 404, 4436-4439. [CrossRef]

104. Botterman, J.; Joos, J.J.; Smet, P.F. Trapping and detrapping in $\mathrm{SrAl}_{2} \mathrm{O}_{4}$ : Eu,Dy persistent phosphors: Influence of excitation wavelength and temperature. Phys. Rev. B 2014, 90, 085147-15. [CrossRef]

105. Anoop, G.; Krishna, K.M.; Jayaraj, M.K. Photoluminescent studies in co-sputtered $\mathrm{ZnGa}_{2} \mathrm{O}_{4}$ : Mn phosphor thin films. In Proceedings of the ASID; New Delhi, India: 8-12 October 2006; pp. 280-282.

106. Yeung, K.M.; Tsang, W.S.; Mak, C.L.; Wong, K.H. Optical studies of ZnS:Mn films grown by pulsed laser deposition. J. Appl. Phys. 2002, 93, 3636-3640. [CrossRef]

107. Geetha, M.; Singh, A.K.; Asokamani, R.; Gogia, A.K. Ti based biomaterials, the ultimate choice for orthopaedic implants-A review. Prog. Mater. Sci. 2009, 54, 397-425. [CrossRef]

108. Jelínek, M.; Vaněk, P.; Tolde, Z.; Buixaderas, E.; Kocourek, T.; Studnička, V.; Drahokoupil, J.; Petzelt, J.; Remsa, J.; Tyunina, M. PLD prepared bioactive $\mathrm{BaTiO}_{3}$ films on TiNb implants. Mater. Sci. Eng. C 2017, 70, 334-339. [CrossRef]

109. Yang, Y.; Wang, Z.; Li, J.; Viehland, D. Pulsed Laser Deposition of $\mathrm{BaTiO}_{3}$ Thin Films on Different Substrates. J. Nanomater. 2010, 2010, 756319. [CrossRef]

110. Liu, Z. Laser Applied Coatings. Ref. Modul. Mater. Sci. Mater. Eng. Shreir's Corros. 2010, 4, $2622-2635$. [CrossRef]

111. Murray, M.; Jose, G.; Richards, B.; Jha, A. Femtosecond pulsed laser deposition of silicon thin films. Nanoscale Res. Lett. 2013, 8, 272. [CrossRef]

Publisher's Note: MDPI stays neutral with regard to jurisdictional claims in published maps and institutional affiliations.

(C) 2020 by the authors. Licensee MDPI, Basel, Switzerland. This article is an open access article distributed under the terms and conditions of the Creative Commons Attribution (CC BY) license (http://creativecommons.org/licenses/by/4.0/). 